\title{
Amino acid efficiencies of utilization vary by different mechanisms in response to energy and protein supplies in dairy cows: Study at mammary-gland and whole-body levels
}

\author{
C. Omphalius, ${ }^{1,2}$ H. Lapierre, ${ }^{3}$ J. Guinard-Flament, ${ }^{1}$ P. Lamberton, ${ }^{1}$ L. Bahloul, ${ }^{2}$ and S. Lemosquet ${ }^{1 *}$ \\ ${ }^{1}$ PEGASE, INRA, Agrocampus Ouest, 35590 Saint Gilles, France \\ ${ }^{2}$ Adisseo France S.A.S., 92160 Antony, France \\ ${ }^{3}$ Agriculture and Agri-Food Canada, Sherbrooke, QC, Canada J1M 0C8
}

\section{ABSTRACT}

Variations of mammary gland (MG) metabolism were studied in dairy cows in response to diets containing 2 levels of net energy of lactation $\left[\mathrm{NE}_{\mathrm{L}} ; 25.0\right.$ and $32.5 \mathrm{Mcal} / \mathrm{d}$ for low (LE) and high energy (HE), respectively], combined with 2 levels of metabolizable protein [MP, 1,266 and 2,254 g/d of protein digestible in the intestine for low (LP) and high protein (HP), respectively] in a $2 \times 2$ factorial arrangement. Four cows received 4 diets (LELP, HELP, LEHP, and HEHP) in a $4 \times 4$ Latin square design with 2 -wk experimental periods. Milk production and feed intake were measured on the last $5 \mathrm{~d}$ of each period, whereas MG net uptake of AA was determined on d 13. Efficiencies were estimated as the sum of measured milk true protein yield (MPY) and of estimations of metabolic fecal and scurf proteins multiplied by their respective AA profile and divided by the estimated AA supply minus the AA endogenous urinary loss. The increased MPY in the HE compared with the LE diets (higher by 123 $\mathrm{g} / \mathrm{d}$ ) was accompanied by increased mammary plasma flow and MG uptake of the nonessential AA (NEAA) and the essential AA (EAA), except for branched-chain AA. In contrast, the increase in MPY (higher by 104 $\mathrm{g} / \mathrm{d}$ ) observed in the HP compared with the LP diets was linked to increased MG uptake of EAA without a change in mammary plasma flow and a decreased NEAA uptake. Because MG uptake of total AA-N was almost equal to cows' milk output on a nitrogen basis, these different mechanisms involve a large MG flexibility, with variable synthesis of NEAA. In addition, MP efficiency did not increase only through increased MPY in the HE compared with the LE diets but also through metabolic fecal protein, estimated to increase (by 65 $\mathrm{g} / \mathrm{d})$ with dry matter intake. The MPY increased in

Received February 5, 2019.

Accepted July 10, 2019.

*Corresponding author: sophie.lemosquet@inra.fr the HP compared with the LP diets, but the increase was smaller than the calculated increase (greater by $993 \mathrm{~g} / \mathrm{d}$ ) in MP supply. The highest MG clearance rates of individual EAA could suggest that Met, His, and Lys were limiting in LP, and Met was the most limiting AA in HP. Interestingly, a similar hypothesis could be stated by analyzing estimated AA efficiencies. The highest efficiencies among EAA, observed for His in HELP and for Met with the other diets, could indicate that they were the most limiting AA in these respective diets, whereas other EAA (including Lys) efficiencies varied with MP efficiency. The MG metabolic flexibility with regard to individual AA utilization partially contributes to the anabolic fate of AA through MPY; however, other export proteins also contribute to variations in MP and AA efficiencies.

Key words: amino acid, efficiency, mammary gland, metabolism

\section{INTRODUCTION}

Increasing dietary $\mathrm{N}$ efficiency (milk $\mathrm{N} / \mathrm{N}$ intake) for lactating dairy cows, without a detrimental effect on milk true protein yield (MPY), is an important challenge faced by dairy nutritionists. Indeed, correctly addressing this challenge has both economic and environmental effects. At the animal level, it is widely acknowledged that MPY increases with either $\mathrm{NE}_{\mathrm{L}}$ or MP supplies (Broderick, 2003), and MP efficiency (MP_eff) decreases with increasing MP (Metcalf et al., 2008) but increases with increasing $\mathrm{NE}_{\mathrm{L}}$ (Hanigan et al., 1998; Rius et al., 2010a). Overall, MP_eff depends on the partition of individual AA between their uses in the different proteins exported and their catabolism. The AA are the nutrients absorbed in the small intestine after MP hydrolysis and taken up by tissues and organs to synthesize all proteins, including milk proteins. Studying mammary gland (MG) metabolism will help us understand MPY responses through variations in MG uptake of AA used to support MPY or catabolized within the MG. For example, MG uptake of 
AA from group 2 (Ile, Leu, Lys, and Val) increased in response to increased MP supply (Raggio et al., 2004). Moreover, this increase was larger than the increase of group $2 \mathrm{AA}$ in milk output, indicating increased MG use of these AA not related to their direct incorporation into MPY, suggesting intramammary catabolism. The effects of $\mathrm{NE}_{\mathrm{L}}$, or of the interaction between $\mathrm{NE}_{\mathrm{L}}$ and MP $(\mathbf{E} \times \mathbf{P})$, on MG use of AA are less studied than the effects of MP supply alone, despite knowing that utilization of AA is an energy-dependent process. Post-ruminal infusion of glucose or ruminal infusion of propionate increased MPY and MG uptake of group 1 AA (His, Met, Phe, and Tyr) without a change in AA supply (Lemosquet et al., 2010a). Moreover, MG uptake of AA from group 2 did not change with these infusions. In most studies analyzing $\mathrm{E} \times \mathrm{P}$ effects on MG metabolism, treatments were infusions of energy sources such as starch, glucose (post-ruminally), or propionate (in rumen), or infusions of AA (in duodenum; e.g., Clark et al., 1977; Raggio et al., 2006a; Rius et al., 2010a; Nichols et al., 2016), but dietary changes could affect MG metabolism differently than infusions of a single substrate (Cantalapiedra-Hijar et al., 2015).

However, these changes in MG metabolism cannot totally explain the variations in MP_eff, because MP_eff depends on both the export of MPY and unproductive protein fractions such as metabolic fecal protein (INRA, 2018; Lapierre et al., 2016). The latter represents the second contributor of protein export after MPY. In addition, extramammary AA metabolism may also be modified, as reported by Raggio et al. (2004), who calculated individual AA efficiencies (AA_eff) as the ratio of individual AA in MPY relative to net portal absorption. These AA_eff decreased with increasing MP supply and were related to increased hepatic removal of Met, Phe, and Tyr (Raggio et al., 2004). These mechanisms could explain the variable AA_eff between AA when increasing AA supply (Doepel et al., 2004). These variations among AA have led to the calculation of individual EAA efficiencies (EAA_eff) rather than MP_eff (Arriola Apelo et al., 2014), using the pattern of calculation of MP_eff as already done in Lee et al. (2015). In addition, some MG metabolism parameters (e.g., uptake to milk output ratio of AA from group 2 or EAA clearance rate) can help to delineate which EAA are extensively catabolized or which have the lowest supplies (Arriola Apelo et al., 2014; Haque et al., 2015).

The present experiment aimed to describe MPY responses to variable $\mathrm{NE}_{\mathrm{L}}$ and $\mathrm{MP}$ supplies occurring via dietary changes and to relate these responses to MG and extramammary uses of AA. We hypothesized that the increased MPY seen with both $\mathrm{NE}_{\mathrm{L}}$ and MP supplies would occur through different mechanisms at the MG level. We also hypothesized that MP_eff and AA_eff variations with $\mathrm{NE}_{\mathrm{L}}$ and $\mathrm{MP}$ supplies could be explained by individual AA metabolism and were partially related to MG metabolism. Last, we hypothesized that different parameters (MG metabolism and individual AA_eff) could be used jointly to identify AA potentially in short supply.

\section{MATERIALS AND METHODS}

\section{Cows and Surgery}

The trial was carried out at the experimental farm of the Institut National de la Recherche Agronomique, Unité Mixte de Recherche, Physiologie, Envionnement et Genetique pour l'Animal et les Systèmes d'Elevage (INRA UMR PEGASE 1348; Méjusseaume, $1.71^{\circ} \mathrm{W}$, $48.11^{\circ} \mathrm{N}$, Brittany, France) in 2007 in accordance with the National Legislation on Animal Care (certified by the French Ministry of Agriculture, Paris; Agreement Number C35-275-23). At $48 \pm 16$ DIM, 4 Holstein cows in their second lactation were surgically implanted with a permanent catheter in the left carotid artery according to Raggio et al. (2006b). For this surgery, protocols for analgesia and anesthesia were followed as described in Haque et al. (2015). To maintain catheter patency, twice every week $10 \mathrm{~mL}$ of blood were drawn by syringe, and then $5 \mathrm{~mL}$ of saline solution followed by $2 \mathrm{~mL}$ of heparin $(5,000 \mathrm{IU} / \mathrm{mL})$ were injected into the catheter. At the same visit, the exteriorization site of the catheter was cleaned with an alcohol and ether mixture, and iodinized alcohol was dripped onto the site. Betadine gel (Meda Pharma, Hoeilaart, Belgium) was then applied and the catheter protected by a bandage. The day before blood collection, using local anesthesia (injection of $2 \mathrm{~mL}$ of Lurocaine; Vetoquinol SA, Lure, France), another catheter (Nutricath S; inner diameter $1.02 \mathrm{~mm}$, outer diameter $1.78 \mathrm{~mm}$; Vygon, Ecouen, France) was temporarily implanted in the left subcutaneous abdominal vein.

Cows began the experiment at $86 \pm 12$ DIM. From 66 to 72 DIM, the cows averaged $593 \pm 19 \mathrm{~kg}$ of BW, 23.0 $\pm 1.2 \mathrm{~kg}$ of DMI/d, and $37.2 \pm 3.0 \mathrm{~kg}$ of milk/d. Milk true protein and fat concentrations were $29.8 \pm 1.6 \mathrm{~g} /$ $\mathrm{kg}$ and $37.0 \pm 1.4 \mathrm{~g} / \mathrm{kg}$, respectively. These production parameters were used as reference values. During the pre-experimental period and throughout the study, cows were housed in individual tiestalls and had ad libitum access to fresh water.

\section{Experimental Design, Diets, Feeding, and Milking}

Diets containing two levels of $\mathrm{NE}_{\mathrm{L}}$ supply [low energy (LE) and high energy (HE)] combined with 2 
levels of MP supply [low protein ( $\mathbf{L P})$ and high protein $(\mathbf{H P})$ ] were tested according to a $2 \times 2$ factorial arrangement. The cows received the 4 diet combinations (LELP, HELP, LEHP, and HEHP) in a $4 \times 4$ Latin square design, balanced for residual effects, with 2 -wk experimental periods. During each period, the supplies of $\mathrm{NE}_{\mathrm{L}}$ and $\mathrm{MP}$ [in $\mathrm{g} / \mathrm{d}$ of protein digestible in the intestine (PDI) in the INRA system] in the LELP diet were adjusted to provide $70 \%$ of cows' $\mathrm{NE}_{\mathrm{L}}$ and $\mathrm{MP}$ requirements (INRA, 1989). To maximize the difference between $\mathrm{NE}_{\mathrm{L}}$ and MP levels, the HEHP diet was designed to provide $100 \%$ of the $\mathrm{NE}_{\mathrm{L}}$ requirement and $125 \%$ of the MP requirement. Assuming no change in $\mathrm{BW}$, the requirements were calculated for each cow in each period using milk yield and composition of the reference period, applying a lactation persistency of $98 \%$ per week, and assuming that milk protein and fat concentrations did not change. The 4 diets included corn silage, an energy concentrate, and formaldehydetreated (FT) soybean meal. The chemical composition of the 3 major ingredients is detailed in Table 1, and complete diet composition is given in Table 2. The difference in the $\mathrm{NE}_{\mathrm{L}}$ supply was obtained by changing the amount of feed offered $(14.7 \pm 0.77$ vs. $19.5 \pm 0.96$ $\mathrm{kg}$ of DM/d for LE vs. HE, respectively) and by altering the proportion of energy concentrate or FT soybean meal (Table 2). A higher MP supply was achieved by substituting energy concentrate with FT soybean meal. We adjusted the quantities offered and the proportion of each ingredient of each diet to each cow's requirements at each period. The daily amount of corn silage offered averaged $12.5 \pm 0.7 \mathrm{~kg}$ of DM in LELP, HELP, and HEHP. To maintain the $\mathrm{NE}_{\mathrm{L}}$ supply in LEHP similar to LELP, we had to reduce the amount of both corn silage and energy concentrate $(8.7 \pm 0.8 \mathrm{~kg}$ of $\mathrm{DM} / \mathrm{d}$ and 0.3 $\pm 0.2 \mathrm{~kg}$ of $\mathrm{DM} / \mathrm{d}$ offered, respectively) and increase MP supply through additional FT soybean meal $(4.9 \pm$ $0.5 \mathrm{~kg}$ of DM for LEHP vs. $1.7 \pm 1.2 \mathrm{~kg}$ of DM for the 3 other diets). Therefore, the percentage of concentrate (FT soybean meal, energy concentrate, and urea) averaged $13.8 \%, 32.3 \%, 36.5 \%$, and $31.4 \%$ in LELP, HELP, LEHP, and HEHP, respectively. Lastly, an adequate rumen balance between soluble $\mathrm{N}$ and fermented organic matter (i.e., energy) was maintained because the calculated rumen protein balance was higher than the recommended $-14.2 \mathrm{~g} / \mathrm{kg}$ of DM (INRA, 2018) in the 4 diets (Table 2).

To minimize postprandial variations in plasma metabolite concentrations, feed access was limited to 1 or $2 \mathrm{~h}$ every $3 \mathrm{~h}$ starting at $0715 \mathrm{~h}$. Silage was offered 3 times per day: $25 \%$ at $0715 \mathrm{~h}, 25 \%$ at $1315 \mathrm{~h}$, and $50 \%$ of the daily allowance at $1915 \mathrm{~h}$. Other ingredients (energy concentrate, FT soybean meal, urea, and mineral and vitamin premix) were offered every $3 \mathrm{~h}$ starting at
0715 h. During blood sampling days, corn silage was distributed in 5 portions: $12.5 \%$ at each of 4 feeding times $(0715 \mathrm{~h}, 1015 \mathrm{~h}, 1315 \mathrm{~h}$, and $1615 \mathrm{~h})$ and $50 \%$ from $1715 \mathrm{~h}$ to $1915 \mathrm{~h}$. For the first $7 \mathrm{~d}$ of each period, cows were milked twice daily at $0630 \mathrm{~h}$ and $1730 \mathrm{~h}$, whereas for the last $7 \mathrm{~d}$ they were milked at $0630 \mathrm{~h}$ and $1830 \mathrm{~h}$, with the udder halves of each cow milked separately.

\section{Sampling and Laboratory Analyses}

Feed. Every day, feed offered and orts (when present) were weighed. A sample of corn silage and orts were collected daily to determine DM concentration; they were dried at $80^{\circ} \mathrm{C}$ for $48 \mathrm{~h}$. Dry matter of corn silage was used to adjust the quantity of wet feed offered, to maintain a constant amount of DM offered. Samples of concentrates were collected on a weekly basis to determine DM content. One pooled sample per feed ingredient was analyzed for chemical composition (Laboratoire de Développement et d'Analyses des Côtes d'Armor, Saint-Brieuc, France). Methods used were in accordance with those recommended by INRA (Baumont et al., 2018a). More specifically, the effective degradability coefficients for $\mathrm{N}(\%)$ were calculated for a passage rate of $6 \%$ per hour, using the nylon bag technique (Michalet-Doreau et al., 1987) for the corn silage and energy concentrate. For energy concentrate and FT soybean meal, the coefficient was calculated from the enzymatic protein degradation, measured according to the method of Aufrère et al. (1991). Although the experiment was conducted in 2007, the dietary supplies of $\mathrm{NE}_{\mathrm{L}}$ and $\mathrm{MP}$ were calculated using the most recent INRA equations (Baumont et al., 2018b), to better account for the digestive interactions between $\mathrm{NE}_{\mathrm{L}}$ and MP than the previous INRA (1989) and to include the effects of DMI and percentage of concentration on microbial protein and the effect of DMI on RUP. In addition, the AA digestible in the intestine (AADI) - that is, the AA supply as \% PDI - was estimated using the INRA (2018) feeding system; these calculations use a fixed AA microbial profile for the digestible microbial protein and the AA profiles of feed ingredients (Table 2) for the digestible RUP fractions from INRA (2018) feed tables. The AADI flow is the AADI multiplied by calculated MP supply.

Milk. On the last $5 \mathrm{~d}$ of each period, milk production was recorded from the left and right udder at each milking, and samples were collected separately to analyze true protein, fat, and SCC via infrared analysis (ISO 9622: ISO, 1999; Milkoscan, Foss Electric, Hillerød, Denmark). On d 13, at the evening milking, milk samples were collected from left-half udder, and sub-samples were frozen $\left(-20^{\circ} \mathrm{C}\right)$ for further analysis. 
Milk lactose content was measured according to Hurtaud et al. (1993), and total $\mathrm{N}$ was determined via the Kjeldahl method. The NPN and noncasein N contents in milk were also obtained using the Kjeldahl method, by mineralization with sulfuric acid at 95 to $97 \%$ and then distillation with boric acid at $50 \mathrm{~g} / \mathrm{L}$. Using the $\mathrm{N}$, NPN, and noncasein $\mathrm{N}$ concentrations, we calculated true protein, CN, and whey protein proportions in milk protein.

Blood. On d 13 of each period, starting at $0700 \mathrm{~h}$, 6 blood samples from each cow were collected at 2-h intervals simultaneously from the arterial and venous catheters. Blood was immediately put on ice and centrifuged for $10 \mathrm{~min}$ at $2,000 \times g$ to yield plasma. To determine AA concentration of each individual sample, $1.0 \mathrm{~g}$ of plasma was added to $0.2 \mathrm{~g}$ of an internal standard containing each AA to be analyzed, labeled with stable isotopes as described in Doepel and Lapierre (2010). The processed samples were stored at $-80^{\circ} \mathrm{C}$ until analyzed for plasma AA concentrations by isotope dilution using gas chromatography/mass spectrometry (model GC 6890-MS 5973, Agilent Technologies, Wilmington, DE), as previously described (Calder et al., 1999). In addition, 1-methyl-His, Arg, Cit, homocysteine, phosphoserine, Orn, and Tau were analyzed using an AA analyzer (Biotronic LCC 5000, Biotronic GmbH, Maintal, Germany). Plasma urea was assayed using a colorimetric enzymatic kit (urease and glutamate dehydrogenase, Urée UV Cinétique; Kone Diagnostics, Evry, France) in a multiparameter analyzer (Kone Instruments Corp., Espoo, Finland).

\section{Calculations and Statistical Analyses}

Calculations. Mammary plasma flow was determined using the Fick principle, with Phe + Tyr as internal markers (Cant et al., 1993). The Fick principle assumes that all MG uptake of Phe and Tyr is from free AA and that there is no other fate for their MG uptake but milk protein secretion. This assumption has been

Table 1. Chemical composition ( $\mathrm{g} / \mathrm{kg}$ of DM unless otherwise noted) of major feed ingredients

\begin{tabular}{|c|c|c|c|}
\hline DM, \% & 45 & 87 & 86 \\
\hline $\mathrm{CP}$ & 67 & 140 & 501 \\
\hline $\mathrm{ADF}$ & 194 & 43 & 66 \\
\hline NDF & 381 & 72 & 140 \\
\hline ADL & 20 & 4 & 4 \\
\hline Ether extract & 30 & 35 & 33 \\
\hline Fermentation products & 61 & & \\
\hline ED6_N ${ }^{3} \%$ & 72 & 92 & $34^{4}$ \\
\hline \multicolumn{4}{|c|}{ AA composition, ${ }^{5} \%$ of 16 AA excluding Cys and $\operatorname{Trp}$ (INRA, 2018) } \\
\hline \multicolumn{4}{|c|}{ EAA } \\
\hline $\operatorname{Arg}$ & 2.1 & 9.1 & 7.7 \\
\hline His & 2.9 & 2.7 & 2.8 \\
\hline Thr & 4.5 & 4.1 & 4.0 \\
\hline Val & 6.3 & 5.1 & 5.1 \\
\hline \multicolumn{4}{|l|}{ NEAA } \\
\hline Ala & 9.0 & 4.8 & 4.6 \\
\hline $\mathrm{Asx}^{6}$ & 8.6 & 12.9 & 12.0 \\
\hline $\mathrm{Glx}^{6}$ & 14.7 & 17.6 & 18.9 \\
\hline Gly & 4.8 & 4.8 & 4.4 \\
\hline Pro & 8.1 & 4.5 & 5.3 \\
\hline Ser & 5.5 & 5.0 & 5.0 \\
\hline Tyr & 4.0 & 3.4 & 3.7 \\
\hline
\end{tabular}

${ }^{1}$ Concentrate contained, on DM basis, $54.2 \%$ peas, $38.2 \%$ cornstarch, $4.4 \%$ sugar molasses, $2.0 \%$ soy oil, and $1.2 \% \mathrm{NaCl}$.

${ }^{2}$ Formaldehyde-treated soybean meal contained $94.7 \%$ soybean meal, $4.2 \%$ sugar molasses, and $1.1 \%$ formol.

${ }^{3}$ Effective degradability of $\mathrm{N}$ in the rumen, calculated for a passage rate of $6 \% / \mathrm{h}$.

${ }^{4}$ Calculated using the enzymatic protein degradation (equal to 7.1\%) according to Aufrère et al. (1991).

${ }^{5}$ Estimated using feed tables ( $\mathrm{n} \geq 48$ for each raw material) and equations 24.6 and 24.5 for concentrate (INRA, 2018).

${ }^{6}$ Called Asp and Glu in INRA (2018) feed tables. 
Table 2. Composition and predicted nutritive values of experimental diets, using INRA (2018)

\begin{tabular}{|c|c|c|c|c|}
\hline \multirow[b]{2}{*}{ Item } & \multicolumn{4}{|c|}{ Diet $^{1}$} \\
\hline & LELP & HELP & LEHP & HEHP \\
\hline Corn silage, $\%$ of $\mathrm{DM}$ & $83.2 \pm 1.5$ & $65.4 \pm 4.0$ & $60.4 \pm 1.1$ & $66.3 \pm 3.8$ \\
\hline Energy concentrate, ${ }^{2} \%$ of DM & $3.0 \pm 2.2$ & $30.5 \pm 3.7$ & $2.3 \pm 1.1$ & $11.9 \pm 4.1$ \\
\hline FT-soybean meal, ${ }^{3} \%$ of DM & $9.7 \pm 0.9$ & $0.8 \pm 0.7$ & $33.9 \pm 1.5$ & $18.7 \pm 1.8$ \\
\hline Minerals and vitamins, ${ }^{4} \%$ of DM & $1.9 \pm 0.2$ & $1.5 \pm 0.0$ & $2.0 \pm 0.2$ & $1.5 \pm 0.2$ \\
\hline Urea, ${ }^{5} \%$ of DM & $1.1 \pm 0.1$ & $1.0 \pm 0.1$ & $0.3 \pm 0.1$ & $0.8 \pm 0.3$ \\
\hline Mineral feed, ${ }^{6} \%$ of DM & $1.1 \pm 0.1$ & $0.8 \pm 0.0$ & $1.1 \pm 0.1$ & $0.8 \pm 0.1$ \\
\hline Quantity offered, $\mathrm{kg}$ of DM/d & $14.8 \pm 0.7$ & $19.2 \pm 0.3$ & $14.5 \pm 0.9$ & $19.8 \pm 1.4$ \\
\hline $\mathrm{CP}, \%$ of DM & 13.9 & 11.8 & 22.2 & 17.6 \\
\hline $\mathrm{MP}, \mathrm{g} / \mathrm{kg} \mathrm{DM}$ of $\mathrm{PDI}^{7}$ & 87.6 & 66.0 & 154.5 & 116.7 \\
\hline $\mathrm{PDIA}^{8} \mathrm{~g} / \mathrm{kg}$ of DM & 39.1 & 16.4 & 106.2 & 68.9 \\
\hline $\mathrm{RPB},{ }^{9} \mathrm{~g} / \mathrm{kg}$ of DM & -0.3 & 2.1 & 14.1 & 6.9 \\
\hline \multicolumn{4}{|l|}{$\mathrm{AADI},{ }^{10} \% \mathrm{PDI}$} & 1.7 \\
\hline His & 2.2 & 2.1 & 2.5 & 2.4 \\
\hline Leu & 8.8 & 8.8 & 8.6 & 8.7 \\
\hline Lys & 7.0 & 7.4 & 6.8 & 6.9 \\
\hline Met & 1.9 & 2.0 & 1.6 & 1.7 \\
\hline \multicolumn{5}{|c|}{$\begin{array}{l}{ }^{1} \text { LELP }=\text { low energy and low protein; HELP }=\text { high energy and low protein; LEHP }=\text { low energy and high } \\
\text { protein; HEHP }=\text { high energy and high protein. Mean } \pm \mathrm{SD} \text {. }\end{array}$} \\
\hline \multicolumn{5}{|c|}{$\begin{array}{l}{ }^{2} \text { Concentrate contained, on DM basis, } 54.2 \% \text { peas, } 38.2 \% \text { cornstarch, } 4.4 \% \text { sugar molasses, } 2.0 \% \text { soy oil, and } \\
1.2 \% \mathrm{NaCl} \text {. }\end{array}$} \\
\hline \multicolumn{5}{|c|}{${ }^{3}$ Formaldehyde-treated soybean meal contained $94.7 \%$ soybean meal, $4.2 \%$ sugar molasses, and $1.1 \%$ formol. } \\
\hline \multicolumn{5}{|c|}{$\begin{array}{l}{ }^{4} \text { Calcium (carbonate): } 200 \mathrm{~g} / \mathrm{kg} \text {; phosphorus: } 90 \mathrm{~g} / \mathrm{kg} \text {; magnesium: } 40 \mathrm{~g} / \mathrm{kg} \text {; sodium: } 20 \mathrm{~g} / \mathrm{kg} \text {; zinc (oxide and } \\
\text { sulfate): } 6,000 \mathrm{mg} / \mathrm{kg} \text {; manganese (oxide and sulfate): } 4,000 \mathrm{mg} / \mathrm{kg} \text {; copper (oxide): } 1,400 \mathrm{mg} / \mathrm{kg} \text {; iodine (po- } \\
\text { tassium iodide): } 100 \mathrm{mg} / \mathrm{kg} \text {; cobalt (carbonate): } 50 \mathrm{mg} / \mathrm{kg} \text {; selenium: } 24 \mathrm{mg} / \mathrm{kg} \text {; vitamin A: } 500,000 \mathrm{IU} / \mathrm{kg} \text {; } \\
\text { vitamin } \mathrm{D}_{3}: 100,000 \mathrm{IU} / \mathrm{kg} \text {; vitamin E: } 2,200 \mathrm{mg} / \mathrm{kg} \text {; vitamin } \mathrm{B}_{1}: 50 \mathrm{mg} / \mathrm{kg} \text { (Turbomine Emeraude, Néolait, } \\
\text { Yffiniac, France). }\end{array}$} \\
\hline \multicolumn{5}{|c|}{$\begin{array}{l}{ }^{5} \text { Urea values were taken from INRA (2018) feed tables as } \mathrm{CP}=2,870 \mathrm{~g} / \mathrm{kg} \text { of DM and all } \mathrm{AA}=0 \% \text { of total } \\
\text { of } 16 \mathrm{AA} \text {, excluding Cys and Trp. }\end{array}$} \\
\hline \multicolumn{5}{|c|}{${ }^{6} \mathrm{CaCO}_{3}$ contained calcium $(38 \%)$ and magnesium (1.5\%; Néolait). } \\
\hline \multirow{2}{*}{\multicolumn{5}{|c|}{$\begin{array}{l}{ }^{7} \mathrm{PDI}=\text { true protein digested in the small intestine supplied by RUP and rumen microbial protein (INRA, } \\
\text { 2018), equivalent to MP. } \\
{ }^{8} \text { PDIA = true digestible RUP (INRA, 2018). }\end{array}$}} \\
\hline & & & & \\
\hline \multicolumn{5}{|c|}{$\begin{array}{l}{ }^{9} \mathrm{RPB}=\text { rumen protein balance, difference between } \mathrm{CP} \text { intake and sum of } \mathrm{RUP}+\text { microbial } \mathrm{CP}+\text { endogenous } \\
\mathrm{CP} \text { (INRA, 2018). }\end{array}$} \\
\hline
\end{tabular}

previously verified, because no Phe or Tyr oxidation was detected when Phe supply was doubled through infusion of labeled Phe (Lemosquet et al., 2010b). The amount of Phe and Tyr exported in milk protein was calculated from the left udder MPY from the evening milking of d 13; the contribution of blood-borne protein (3.23\%, adapted from Lapierre et al., 2016; sum of albumin $1.04 \%$, IgG1 1.64\%, IgGA $0.04 \%$, IgG2 0.18\%, and IgM $0.33 \%$ ) was excluded so that only proteins synthesized within the MG from free plasma AA were considered. The AA composition of milk protein was estimated for each cow for each period from the proportion of measured $\mathrm{CN}$ and whey proteins relative to total true protein multiplied by the AA composition of each family of protein reported by Farrell et al. (2004), excluding the contribution of blood-borne protein. The CN distribution (\% of CN) was $42.4 \% \alpha_{\mathrm{s} 1}$-casein, 9.3\% $\alpha_{\mathrm{s} 2}$-casein, $36.7 \% \beta$-casein, and $11.6 \%$ k-casein, and the whey protein distribution (\% of whey protein) was $72.8 \% \alpha$-lactalbumin and $27.2 \% \quad \beta$-lactoglobulin. Although total CN and whey protein proportions, expressed in percent of true protein, changed for each cow for each period as measured, lactoferrin and bloodborne protein concentrations were assumed to remain constant (percent of true protein: lactoferrin $0.21 \%$; and blood-borne protein $3.23 \%$, as detailed previously). The MG uptake of each AA was calculated by multiplying the AA arteriovenous ( $\mathbf{A V}$ ) plasma concentration difference by the mammary plasma flow and is reported in mmol of $\mathrm{N} / \mathrm{h}$. The mammary clearance rate $(\mathrm{L} / \mathrm{h})$ was calculated as MG uptake divided by venous concentration of each AA (Hanigan et al., 1998).

The estimated MP_eff was calculated as proposed in INRA (2018), as the sum of export proteins (i.e., measured MPY and estimated metabolic fecal and scurf proteins) divided by calculated MP supply minus estimated endogenous urinary losses. Because endogenous urinary losses are not protein per se but end products 
Table 3. Amino acid composition of proteins used in the calculations ${ }^{1}$

\begin{tabular}{|c|c|c|c|c|c|}
\hline Item & Scurf & $\begin{array}{l}\text { Endogenous } \\
\text { urinary urea }\end{array}$ & $\begin{array}{c}\text { Metabolic } \\
\text { fecal protein }\end{array}$ & $\begin{array}{l}\text { Milk, excluding } \\
\mathrm{BBP}^{2,3}\end{array}$ & $\begin{array}{l}\text { Milk, including } \\
\mathrm{BBP}^{2,4}\end{array}$ \\
\hline $\operatorname{Arg}$ & 93.2 & 79.7 & 57.2 & $36.2 \pm 0.7$ & $37.0 \pm 0.5$ \\
\hline His & 16.9 & 29.4 & 31.4 & $28.8 \pm 0.3$ & $28.8 \pm 0.3$ \\
\hline Ile & 27.4 & 36.6 & 53.4 & $63.6 \pm 0.3$ & $62.8 \pm 0.3$ \\
\hline Leu & 69.4 & 82.9 & 91.8 & $105.9 \pm 1.6$ & $106.2 \pm 1.6$ \\
\hline Lys & 55.9 & 78.3 & 75.3 & $89.3 \pm 1.2$ & $89.1 \pm 1.2$ \\
\hline Met & 13.7 & 23.3 & 17.0 & $30.3 \pm 0.2$ & $29.9 \pm 0.2$ \\
\hline Phe & 36.6 & 44.7 & 53.4 & $51.6 \pm 0.6$ & $51.9 \pm 0.6$ \\
\hline Thr & 40.6 & 49.0 & 74.3 & $45.7 \pm 0.3$ & $46.4 \pm 0.3$ \\
\hline Trp & 7.7 & 11.0 & 18.7 & $16.6 \pm 0.6$ & $17.1 \pm 0.6$ \\
\hline Val & 46.7 & 51.6 & 70.0 & $69.3 \pm 0.4$ & $69.2 \pm 0.4$ \\
\hline Ala & 92.2 & 85.4 & 63.3 & $36.1 \pm 0.7$ & $36.6 \pm 0.7$ \\
\hline Asn & & & & $45.0 \pm 0.5$ & $44.5 \pm 0.5$ \\
\hline Asp & & & & $38.5 \pm 1.7$ & $39.1 \pm 1.6$ \\
\hline Asx & 84.2 & 96.4 & 75.5 & & \\
\hline Cys & 28.8 & 18.6 & 35.3 & $9.5 \pm 1.4$ & $10.6 \pm 1.3$ \\
\hline Gln & & & & $96.3 \pm 1.3$ & $94.7 \pm 1.3$ \\
\hline Glu & & & & $129.9 \pm 0.7$ & $128.6 \pm 0.7$ \\
\hline Glx & 147.4 & 158.2 & 156.9 & & \\
\hline Gly & 209.7 & 143.9 & 83.9 & $19.1 \pm 0.1$ & $19.8 \pm 0.1$ \\
\hline Pro & 123.6 & 98.2 & 84.2 & $102.1 \pm 2.6$ & $100.9 \pm 2.5$ \\
\hline Ser & 65.0 & 57.8 & 77.6 & $66.2 \pm 1.0$ & $66.4 \pm 0.9$ \\
\hline Tyr & 26.5 & 31.2 & 47.0 & $58.4 \pm 0.7$ & $58.2 \pm 0.6$ \\
\hline
\end{tabular}

${ }^{1}$ Based on Lapierre et al. (2016), data expressed in $\mathrm{g}$ of anhydrous AA per $\mathrm{kg}$ of true protein.

${ }^{2}$ Average of 16 data points (cow $\times$ period).

${ }^{3} \mathrm{BBP}=$ blood-borne proteins; for calculation of the mammary plasma flow and AA in milk protein output used for the calculation of mammary uptake:output ratio.

${ }^{4}$ For calculation of efficiency.

of AA metabolism, the MP_eff and AA_eff for this exportation are assumed to be 1 (INRA, 2018); they are not included in the protein output and are excluded from the protein supply. Although proposed by INRA (2018), we did not consider the potential variation of body reserves (protein mobilization or deposition) according to energy balance, because of the dichotomy created between $\mathrm{NE}_{\mathrm{L}}$ and MP supplies related to the nature of the experimental diets. The estimation of individual AA_eff was calculated similarly, using the estimated AADI supply and the different protein outputs with their respective AA concentrations (Table 3 ). In terms of total $\mathrm{N}$, endogenous urinary losses estimations are very similar between INRA (2018), at $50 \mathrm{mg}$ of $\mathrm{N} / \mathrm{kg}$ of BW, and Lapierre et al. (2016) at $53 \mathrm{mg}$ of $\mathrm{N} / \mathrm{kg}$ of BW. However, the latter defines an AA composition of endogenous urinary excretion based on the different urinary $\mathrm{N}$ fractions of this exportation and their AA precursors. We used the AA composition of the empty body to determine the endogenous urea excretion (Table 3). We considered His as the precursor for 3-methyl-His; Arg and Gly for creatinine and creatine; Asp, Glu, and Gly for purine derivatives; and Gly for hippuric acid. The AA composition of milk was estimated as described above for the calculation of MG metabolism but included the blood-borne protein (Table 3). Finally, the estimated catabolism, which ex- presses the inefficiency in absolute numbers rather than as ratios of efficiencies, is calculated as supply minus all exportations (endogenous urinary losses, MPY, and metabolic fecal and scurf proteins).

Statistical Analyses. Intake and milk yields and composition from the last $5 \mathrm{~d}$ of each period were averaged and used for statistical analyses, whereas the daily means of the 6 blood samples collected on d 13 were used for mammary metabolism and associated calculations. The data were analyzed using the MIXED procedure of SAS v. 9.4 (SAS Institute Inc., Cary, NC), according to the following statistical model:

$$
\begin{aligned}
\mathrm{Y}_{\mathrm{ijkl}}=\mu & +\operatorname{cow}_{\mathrm{i}}+\operatorname{period}_{\mathrm{j}}+\text { energy }_{\mathrm{k}}+\operatorname{protein}_{\mathrm{l}} \\
& +\left(\text { energy } \times \operatorname{protein}_{\mathrm{kl}}+\varepsilon_{\mathrm{ijk} \mathrm{k}},\right.
\end{aligned}
$$

where $\mu$ is the mean; $Y_{\mathrm{ijkl}}$ is the dependent variable for the fixed effects of period ${ }_{j}$ (4 periods), energy $y_{k}$ (energy supply, LE or HE), $\operatorname{protein}_{1}$ (protein supply, LP or HP), and their interaction; and $\varepsilon_{\mathrm{ijkl}}$ is the residual error associated with ijkl observations. Cow was treated as a random effect. As the Latin square was balanced for residual effects, these effects were tested and found not significant $(P>0.20)$ for any of the 4 treatments, which means that there was no carryover effect. The results are presented as least squares means, with the highest 
standard error of the means reported. Homogeneity of residues was verified. The significance level was set to $P \leq 0.05$ and the tendency to $0.05<P \leq 0.10$. If the $\mathrm{E}$ $\times \mathrm{P}$ interaction was significant, the SLICE procedure was used to test the effect of one factor within the other factor.

\section{RESULTS}

\section{DMI and Supplies}

Dry matter intakes (Table 4) were close to the quantities offered (Table 2) because refusals were very small (in kg of DM/d; LELP: 0.07; HELP: 0.36; LEHP: 0.09; HEHP: 0.27; not different from $0, P>0.05$, SEM = $0.26)$. As planned, DMI was greater for the HE diets than for the LE diets $(P<0.01$, Table 4$)$. The calculated $\mathrm{NE}_{\mathrm{L}}$ supply was $30 \%$ greater with the $\mathrm{HE}$ diets than with the LE diets, whereas calculated MP supply was $78 \%$ greater in HP than in LP diets. According to the NRC system (NRC, 2001), $\mathrm{NE}_{\mathrm{L}}$ supply increased by
26\% (in Mcal/d; LELP: 23.4; HELP: 29.9; LEHP: 25.4; HEHP: 31.5 ) and MP supply by $81 \%$ (in g/d; LELP: 1,514; HELP: 1,396; LEHP: 2,651; HEHP: 2,632). With increasing $\mathrm{NE}_{\mathrm{L}}$ supply (HE vs. LE diets), the estimated flow of digestible His decreased $(P=0.03)$, the estimated flow of digestible Arg tended to decrease $(P=$ $0.09)$, and the estimated flow of digestible Thr and Met increased $(P \leq 0.04)$, mainly in HP diets for Met $(\mathrm{E} \times$ $\mathrm{P}$ interaction: $P=0.08$; Table 4$)$. With increasing MP supply (HP vs. LP diets), the digestible flows of all AA increased $(P<0.01)$ in variable proportions; Met flow increased by $52 \%$, whereas flows of Arg and His were doubled.

\section{Milk Production and Composition}

During the last $5 \mathrm{~d}$ of each period, increasing the $\mathrm{NE}_{\mathrm{L}}$ supply increased milk yield, MPY, and milk protein content by 13,19 , and $6 \%$, respectively $(P \leq 0.03$, Table $5)$. Increasing the MP supply increased milk yield and MPY by 17 and $15 \%$, respectively $(P<0.01)$, but did

Table 4. Dry matter intake, calculated protein and energy supplies, and estimated AA digestible flow in the intestine from the experimental diets

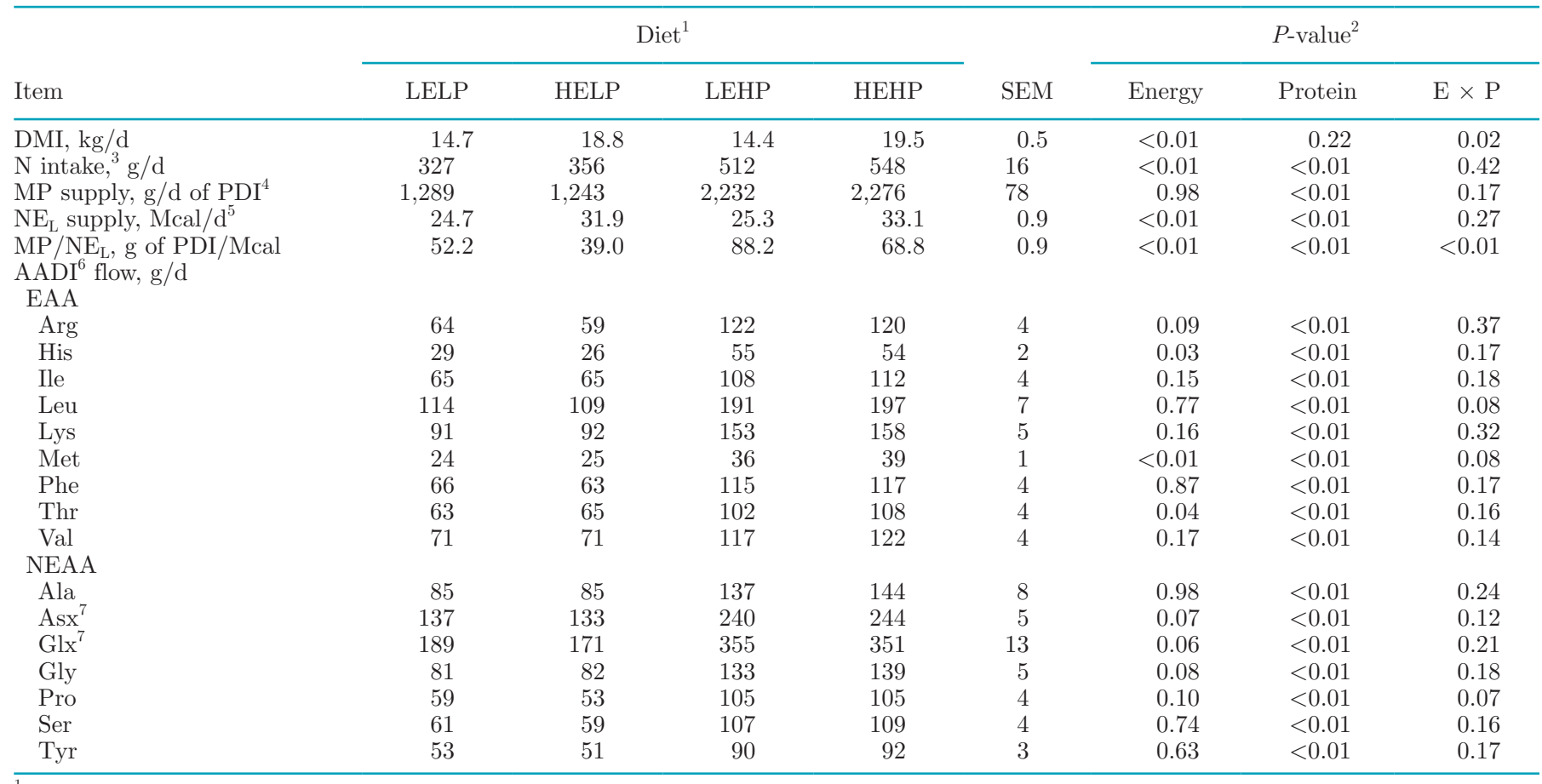

${ }^{1}$ LELP $=$ low energy and low protein; HELP $=$ high energy and low protein; LEHP $=$ low energy and high protein; HEHP $=$ high energy and high protein.

${ }^{2} P$-values correspond to the effect of energy supply (LE vs. HE), effect of protein supply (LP vs. HP), and interaction between energy and protein $(\mathrm{E} \times \mathrm{P})$.

${ }^{3} \mathrm{~N}$ intake $=\mathrm{CP}$ intake $/ 6.25$.

${ }^{4} \mathrm{PDI}=$ protein digested in the small intestine, supplied by RUP and rumen microbial protein (calculated by INRA, 2018), equivalent to MP. ${ }^{5}$ Calculated in INRA (2018).

${ }^{6} \mathrm{AADI}=\mathrm{AA}$ digestible in the small intestine $(\%$ PDI, estimated by INRA, 2018, equations and feed tables $) \times \mathrm{MP}$.

${ }^{7}$ Called Asp and Glu in INRA (2018) feed tables. 
Table 5. Milk yield and milk composition from samples collected from the whole udder on the last $5 \mathrm{~d}$ and from left-half udder during the evening milking of $\mathrm{d} 13$

\begin{tabular}{|c|c|c|c|c|c|c|c|c|}
\hline \multirow[b]{2}{*}{ Item } & \multicolumn{4}{|c|}{ Diet $^{1}$} & \multirow[b]{2}{*}{ SEM } & \multicolumn{3}{|c|}{$P$-value ${ }^{2}$} \\
\hline & LELP & HELP & LEHP & HEHP & & Energy & Protein & $\mathrm{E} \times \mathrm{P}$ \\
\hline Milk yield, $\mathrm{kg} / \mathrm{d}$ & 24.2 & 26.5 & 27.6 & 31.8 & 1.3 & $<0.01$ & $<0.01$ & 0.11 \\
\hline Milk protein yield, ${ }^{3} \mathrm{~g} / \mathrm{d}$ & 654 & 757 & 736 & 891 & 43 & $<0.01$ & $<0.01$ & 0.16 \\
\hline Milk protein content, ${ }^{3} \mathrm{~g} / \mathrm{kg}$ & 26.9 & 28.9 & 26.9 & 28.1 & 1.6 & 0.03 & 0.46 & 0.50 \\
\hline Fat content, $\mathrm{g} / \mathrm{kg}$ & 38.6 & 41.5 & 37.1 & 40.3 & 1.6 & 0.06 & 0.36 & 0.91 \\
\hline Milk protein yield,$^{3} \mathrm{~g} / 12 \mathrm{~h}$ & 148 & 172 & 169 & 206 & 9 & $<0.01$ & $<0.01$ & 0.31 \\
\hline Milk protein content, ${ }^{3} \mathrm{~g} / \mathrm{kg}$ & 26.3 & 27.9 & 26.4 & 27.7 & 1.5 & 0.03 & 0.91 & 0.69 \\
\hline Casein, $\%$ of TP & 80.3 & 78.8 & 79.0 & 80.5 & 1.7 & 0.99 & 0.72 & 0.03 \\
\hline $\mathrm{CP},{ }^{4} \mathrm{~g} / \mathrm{kg}$ & 27.6 & 28.8 & 28.6 & 29.6 & 1.5 & 0.09 & 0.17 & 0.83 \\
\hline NPN, \% CP & 6.70 & 4.74 & 8.74 & 7.18 & 0.54 & $<0.01$ & $<0.01$ & 0.58 \\
\hline Lactose content, $\mathrm{g} / \mathrm{kg}$ & 46.9 & 47.7 & 46.1 & 48.0 & 1.4 & 0.05 & 0.70 & 0.30 \\
\hline
\end{tabular}

${ }^{1}$ LELP $=$ low energy and low protein; HELP = high energy and low protein; LEHP = low energy and high protein; HEHP = high energy and high protein.

${ }^{2} P$-values correspond to the effect of energy supply (LE vs. HE), effect of protein supply (LP vs. HP), and interaction between energy and protein $(\mathrm{E} \times \mathrm{P})$.

${ }^{3}$ Expressed in true protein (TP).

${ }^{4} \mathrm{CP}=$ total milk $\mathrm{N} \times 6.39$.

not affect milk protein content $(P=0.46)$. We observed similar increases in milk yield and milk composition in response to $\mathrm{HE}$ compared with LE diets or to HP compared with LP diets from the left udder evening milking on d 13 (used for MG uptake measurement). The proportion of NPN relative to $\mathrm{CP}$ decreased by $23 \%(P<0.01)$ in HE compared with LE diets and increased by $39 \%$ in HP compared with LP diets $(P$ $<0.01$, Table 5). We observed an $\mathrm{E} \times \mathrm{P}$ interaction $(P=0.03)$ for the proportion of $\mathrm{CN}$ in true protein; increasing the $\mathrm{NE}_{\mathrm{L}}$ supply tended to decrease $\mathrm{CN}$ with the LP diets $(P=0.08$ from the slice test) but tended to increase $\mathrm{CN}$ with the HP $\operatorname{diets}(P=0.08)$.

\section{Amino Acid Mammary Metabolism}

Plasma Arterial Concentrations. The arterial concentration of urea decreased in HE compared with LE diets $(P<0.01$, Table 6$)$ and increased in HP compared with LP diets $(P<0.01)$. Plasma arterial concentrations of total AA on nitrogen basis (TAA$\mathbf{N}$ ), EAA-N, and NEAA-N were not affected by the $\mathrm{NE}_{\mathrm{L}}$ supply $(P>0.10$, Table 6$)$. Increasing the $\mathrm{NE}_{\mathrm{L}}$ supply decreased $(\mathrm{E} \times \mathrm{P}$ interaction: $P=0.04)$ the arterial concentration of group 1 AA-N [sum of Met, Phe, Trp, and Tyr (Mepham, 1982) plus His] only in LP diets. For individual EAA, increasing the $\mathrm{NE}_{\mathrm{L}}$ supply decreased $(P<0.02)$ concentrations of Arg and Phe and those of His $(\mathrm{E} \times \mathrm{P}$ interaction: $P=0.03)$ but only in LP diets. In contrast, concentrations of Thr and Ser increased $(\mathrm{E} \times \mathrm{P}$ interaction: $P \leq 0.04)$ only in $\mathrm{LP}$ diets. Among NEAA, the HE diets increased Gly $(P<$
$0.01)$, decreased Cit $(P=0.03)$, and tended $(P=0.09)$ to decrease Cys concentrations compared with those in the LE diets.

Increasing the MP supply increased $(P<0.01)$ arterial plasma concentration of TAA-N, EAA-N, group 2 AA-N, and branched-chain AA-N (BCAA-N). Group 1 AA-N also increased with HP diets, but the effect was greater with $\mathrm{HE}$ rather than with LE diets $(\mathrm{E} \times$ $\mathrm{P}$ interaction: $P=0.04)$. In contrast, we found no MP effect $(P=0.18)$ on NEAA-N concentrations. Increasing the MP supply increased the arterial concentration of all EAA $(P<0.01)$ except Met $(P=0.67)$. Arterial concentration of Thr increased $(\mathrm{E} \times \mathrm{P}$ interaction: $P$ $<0.01)$ in HP compared with LP diets in LE but not in HE diets. The increase in His arterial concentration with HP compared with LP diets was less pronounced in $\mathrm{LE}$ than in $\mathrm{HE}$ diets $(\mathrm{E} \times \mathrm{P}$ interaction: $P=0.03)$. Arterial concentrations were higher for Cit, Orn, Pro, and Tyr in HP diets than in LP diets $(P<0.01)$, lower for Gly $(P<0.01)$, and tended to be lower for Asp and Gln $(P \leq 0.07)$.

Arteriovenous Concentration Differences. The AV difference of TAA-N and EAA-N decreased $(P \leq$ 0.02 , Table 7) and that of group 1 AA-N tended to decrease $(P=0.06)$ in HE compared with LE diets. Individually, increasing the $\mathrm{NE}_{\mathrm{L}}$ supply decreased $\mathrm{AV}$ differences of Arg, Pro, and Ser $(P \leq 0.01)$ and tended to decrease the AV difference of Ile $(P=0.08)$.

Increasing the MP supply increased $(P \leq 0.05)$ the AV differences of TAA-N, EAA-N, group 2 AA-N, and BCAA-N, and tended to increase those of group 1 AA-N $(P=0.10)$. Increasing the MP supply increased 
AV differences of Arg, Ile, Leu, and Phe $(P \leq 0.05)$ and tended to increase that of Val $(P=0.10)$. Increasing the MP supply decreased the AV difference of Ala $(P$ $<0.01)$ and increased the AV difference of $\operatorname{Orn}(P=$ $0.04)$.

Mammary Net Uptake of AA. Mammary plasma flow was greater $(P<0.01)$ in the HE diets than in the LE diets but was not affected by MP supply (Table 7).
Increasing the $\mathrm{NE}_{\mathrm{L}}$ supply increased uptake of TAA-N, EAA-N, and group 1 AA-N $(P \leq 0.02)$ and tended to increase uptake of group 2 AA-N and NEAA-N $(P \leq$ 0.08; Table 8). With HE compared with LE diets, the uptake of Lys, Met, Phe, and Thr increased $(P \leq 0.04)$, and the uptake of His tended to increase but only in the HEHP diet compared with the 3 other diets $(\mathrm{E} \times \mathrm{P}$ interaction: $P=0.09)$. Among the NEAA, the uptake

Table 6. Effects of $\mathrm{NE}_{\mathrm{L}}$ and MP supplies on plasma arterial concentration of urea $\mathrm{N}$ and $\mathrm{AA}$

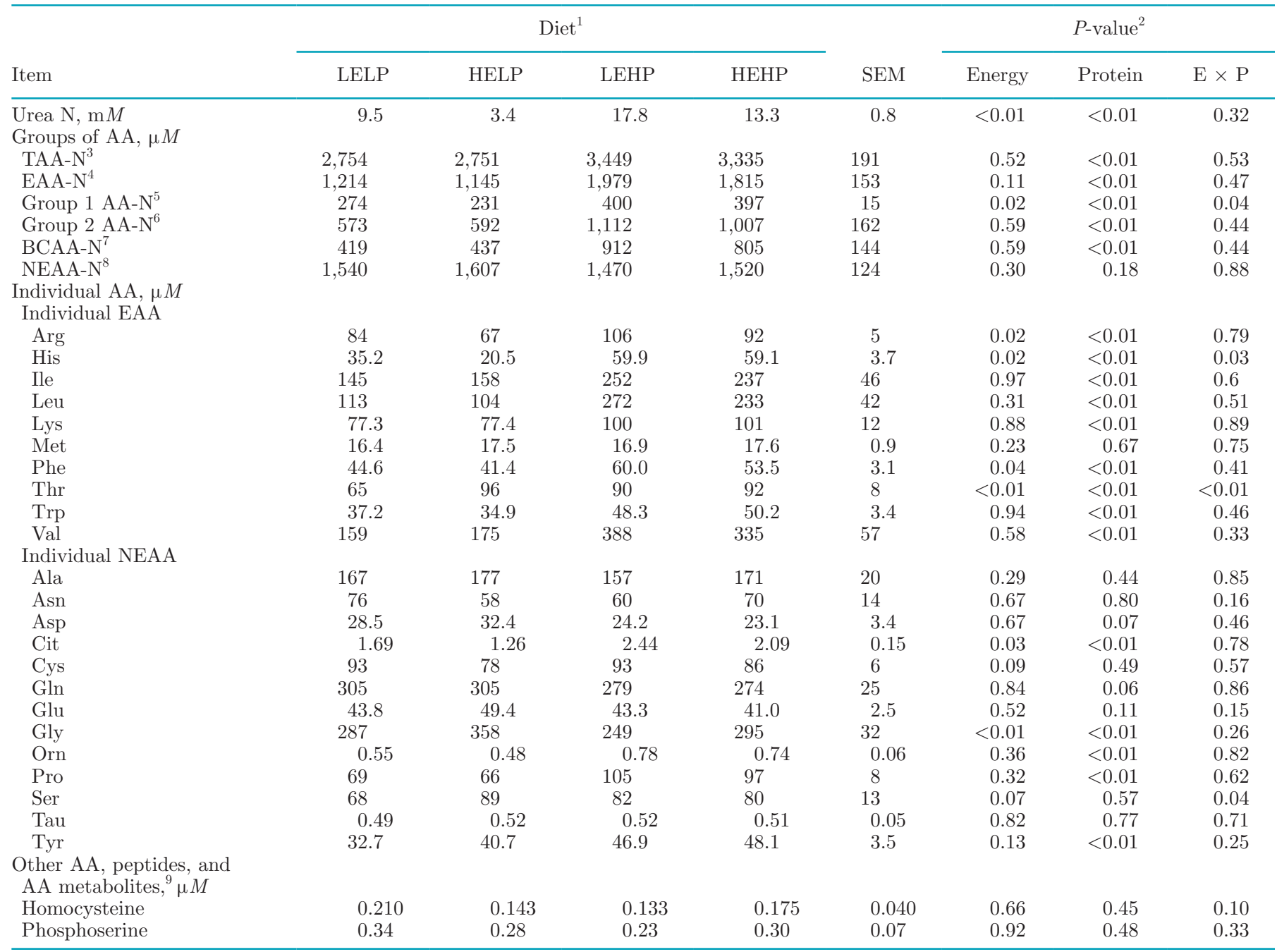

${ }^{1}$ LELP $=$ low energy and low protein; HELP = high energy and low protein; LEHP = low energy and high protein; HEHP = high energy and high protein.

${ }^{2} P$-values correspond to the effect of energy supply (LE vs. HE), effect of protein supply (LP vs. HP), and interaction between energy and protein $(\mathrm{E} \times \mathrm{P})$.

${ }^{3}$ TAA-N $=$ total AA on nitrogen basis.

${ }^{4}$ EAA-N = sum of $\mathrm{N}$ from Arg, His, Ile, Leu, Lys, Met, Phe, Thr, Trp, and Val.

${ }^{5}$ Group 1 AA-N $=$ sum of $\mathrm{N}$ from His, Met, Phe, Trp, and Tyr.

${ }^{6}$ Group 2 AA-N = sum of $\mathrm{N}$ from Ile, Leu, Lys, and Val.

${ }^{7} \mathrm{BCAA}-\mathrm{N}$ = branched-chain AA on nitrogen basis; sum of $\mathrm{N}$ from Ile, Leu, and Val.

${ }^{8}$ NEAA-N $=$ sum of N from Ala, Asn, Asp, Cit, Cys, Gln, Glu, Gly, Orn, Pro, Ser, Tau, and Tyr.

${ }^{9}$ Other nitrogen derivatives measured with a plasma concentration higher than the limit of quantification. 
Table 7. Effects of $\mathrm{NE}_{\mathrm{L}}$ and MP supplies on mammary plasma flow and arteriovenous (AV) differences of AA

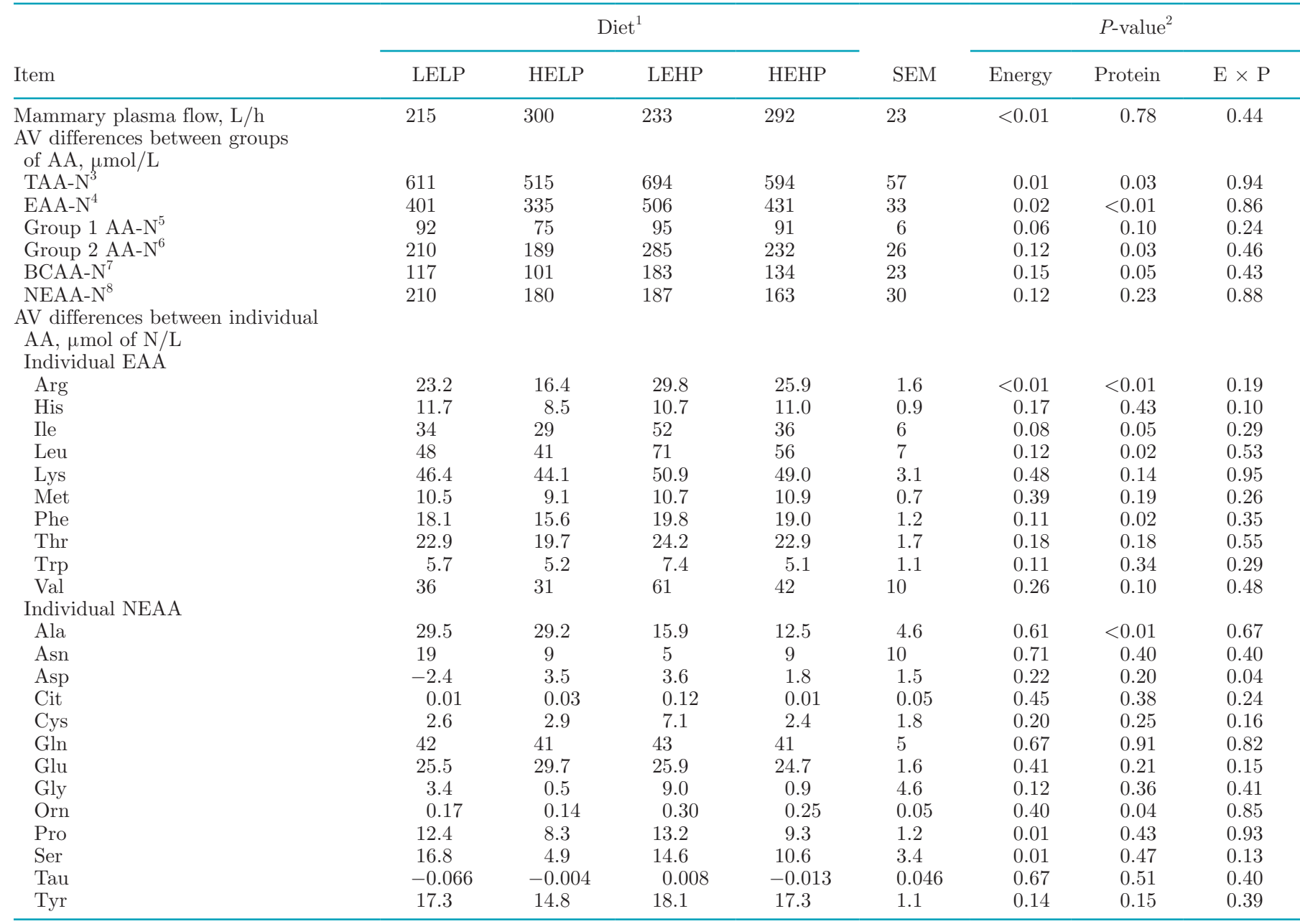

${ }^{1}$ LELP $=$ low energy and low protein; HELP = high energy and low protein; LEHP = low energy and high protein; HEHP = high energy and high protein.

${ }^{2} P$-values correspond to the effect of energy supply (LE vs. HE), effect of protein supply (LP vs. HP), and interaction between energy and protein $(\mathrm{E} \times \mathrm{P})$.

${ }^{3}$ TAA-N $=$ total AA on nitrogen basis.

${ }^{4}$ EAA-N = sum of $\mathrm{N}$ from Arg, His, Ile, Leu, Lys, Met, Phe, Thr, Trp, and Val.

${ }^{5}$ Group 1 AA-N $=$ sum of $\mathrm{N}$ from His, Met, Phe, Trp, and Tyr.

${ }^{6}$ Group 2 AA-N $=$ sum of $\mathrm{N}$ from Ile, Leu, Lys, and Val.

${ }^{7}$ BCAA-N = branched-chain AA on nitrogen basis; sum of $\mathrm{N}$ from Ile, Leu, and Val.

${ }^{8}$ NEAA-N $=$ sum of N from Ala, Asn, Asp, Cit, Cys, Gln, Glu, Gly, Orn, Pro, Ser, Tau, and Tyr.

of Gln and Tyr increased $(P \leq 0.05)$ with the HE diets compared with the LE diets, whereas the uptake of Glu increased to a greater extent in LP than in HP diets $(\mathrm{E} \times \mathrm{P}$ interaction: $P=0.05)$ with $\mathrm{HE}$ compared with LE diets.

With increasing MP supply, uptake of all groups of AA except NEAA-N increased $(P \leq 0.03)$. Mammary uptake of most EAA (Arg, Ile, Leu, Lys, Phe, Thr, and Val) was lower $(P \leq 0.03)$ with the LP diets than with the HP diets. Increasing the MP supply did not affect uptake of $\operatorname{Trp}(P=0.22)$ and tended to increase uptake of Met $(P=0.10)$. Uptake of His tended to differ among MP diets $(\mathrm{E} \times \mathrm{P}$ interaction: $P=0.09)$, with an increase only in HE diets. Uptake of NEAA decreased for Ala $(P<0.01)$, increased for Tyr $(P=$ $0.02)$, and tended to increase for Orn $(P=0.07)$ in HP compared with LP diets.

Mammary Clearance Rate of AA. The mammary clearance rates of TAA-N increased $(P=0.03$; Table 9) and group 1 AA-N tended to increase $(P=$ 0.09) in HE compared with LE diets. The clearance rates of Phe increased $(P \leq 0.02)$, whereas those of Thr 
Table 8. Effects of $\mathrm{NE}_{\mathrm{L}}$ and $\mathrm{MP}$ supplies on left-udder uptake of $\mathrm{AA}^{1}$

\begin{tabular}{|c|c|c|c|c|c|c|c|c|}
\hline AA & \multicolumn{4}{|c|}{ Diet $^{2}$} & SEM & \multicolumn{3}{|c|}{$P$-value ${ }^{3}$} \\
\hline \multicolumn{9}{|c|}{ Uptake of groups of $\mathrm{AA}, \mathrm{mmol} / \mathrm{h}$} \\
\hline $\mathrm{EAA}-\mathrm{N}^{5}$ & 83.5 & 93.9 & 110.8 & 122.4 & 3.7 & 0.02 & $<0.01$ & 0.86 \\
\hline Group 1 AA-N ${ }^{6}$ & 17.4 & 18.8 & 18.6 & 23.3 & 1.3 & 0.02 & 0.03 & 0.14 \\
\hline Group $2 \mathrm{AA}-\mathrm{N}^{7}$ & 45.0 & 54.7 & 63.5 & 67.4 & 3.1 & 0.07 & $<0.01$ & 0.39 \\
\hline \multirow{2}{*}{\multicolumn{9}{|c|}{$\begin{array}{l}\text { Uptake of individual AA, mmol of } \mathrm{N} / \mathrm{h} \\
\text { Individual EAA }\end{array}$}} \\
\hline & & & & & & & & \\
\hline $\operatorname{Arg}$ & 19.9 & 19.0 & 27.3 & 30.1 & 1.8 & 0.62 & $<0.01$ & 0.36 \\
\hline His & 7.6 & 7.4 & 7.5 & 9.6 & 0.8 & 0.13 & 0.11 & 0.09 \\
\hline Ile & 7.2 & 8.4 & 11.2 & 10.4 & 0.8 & 0.82 & 0.01 & 0.28 \\
\hline Leu & 10.3 & 11.7 & 15.8 & 16.2 & 1.0 & 0.37 & $<0.01$ & 0.64 \\
\hline Lys & 20.0 & 25.7 & 23.3 & 28.5 & 1.4 & $<0.01$ & 0.03 & 0.85 \\
\hline \multicolumn{9}{|l|}{ Individual NEAA } \\
\hline Ala & 6.6 & 8.8 & 3.7 & 3.6 & 1.4 & 0.31 & 0.01 & 0.28 \\
\hline Asn & 7 & 5 & 2 & 5 & 5 & 0.91 & 0.53 & 0.56 \\
\hline Asp & -0.6 & 1.1 & 1.0 & 0.5 & 0.4 & 0.26 & 0.30 & 0.05 \\
\hline Cit & 0.00 & 0.05 & 0.15 & 0.03 & 0.07 & 0.55 & 0.35 & 0.26 \\
\hline Cys & 0.51 & 0.84 & 1.48 & 0.68 & 0.34 & 0.48 & 0.23 & 0.11 \\
\hline Gln & 17.8 & 23.0 & 19.5 & 23.8 & 2.0 & 0.05 & 0.55 & 0.82 \\
\hline Glu & 5.5 & 8.9 & 5.9 & 7.2 & 0.5 & $<0.01$ & 0.17 & 0.05 \\
\hline Gly & 0.6 & -0.1 & 1.7 & 0.2 & 0.9 & 0.13 & 0.31 & 0.53 \\
\hline Orn & 0.078 & 0.081 & 0.152 & 0.155 & 0.033 & 0.94 & 0.07 & 1.00 \\
\hline Pro & 2.67 & 2.41 & 2.95 & 2.72 & 0.22 & 0.21 & 0.14 & 0.96 \\
\hline Ser & 3.6 & 1.1 & 3.5 & 3.0 & 0.9 & 0.12 & 0.30 & 0.25 \\
\hline Tau & -0.013 & -0.005 & 0.002 & -0.003 & 0.012 & 0.91 & 0.50 & 0.62 \\
\hline Tyr & 3.74 & 4.27 & 4.14 & 5.03 & 0.25 & 0.01 & 0.02 & 0.37 \\
\hline
\end{tabular}

${ }^{1}$ Mammary net uptake of homocysteine and phosphoserine, shown in Table 6, were not significantly different from zero, so were not reported in this table.

${ }^{2}$ LELP $=$ low energy and low protein; HELP $=$ high energy and low protein; LEHP $=$ low energy and high protein; HEHP $=$ high energy and high protein.

${ }^{3} P$-values correspond to the effect of energy supply (LE vs. HE), effect of protein supply (LP vs. HP), and interaction between energy and protein $(\mathrm{E} \times \mathrm{P})$.

${ }^{4}$ TAA-N $=$ total AA on nitrogen basis.

${ }^{5}$ EAA-N = sum of $\mathrm{N}$ from Arg, His, Ile, Leu, Lys, Met, Phe, Thr, Trp, and Val.

${ }^{6}$ Group 1 AA-N $=$ sum of $\mathrm{N}$ from His, Met, Phe, Trp, and Tyr.

${ }^{7}$ Group 2 AA-N = sum of $\mathrm{N}$ from Ile, Leu, Lys, and Val.

${ }^{8}$ BCAA-N $=$ branched-chain AA on nitrogen basis; sum of $\mathrm{N}$ from Ile, Leu, and Val.

${ }^{9}$ NEAA-N $=$ sum of N from Ala, Asn, Asp, Cit, Cys, Gln, Glu, Gly, Orn, Pro, Ser, Tau, and Tyr.

tended to decrease $(P \leq 0.09)$ with increasing the $\mathrm{NE}_{\mathrm{L}}$ supply. The HP compared with LP diets decreased $(P$ $<0.05)$ the mammary clearance rates of EAA-N, group 1 AA-N and group 2 AA-N, and TAA-N $(P<0.10)$, and had no effect on the mammary clearance rate of NEAA-N. The clearance rates of His, Leu, Lys, Trp, and Val decreased $(P \leq 0.05)$, whereas the clearance rate of Phe only tended to decrease $(P=0.10)$ in HP compared with LP diets.

AA Exported in Milk Protein and Ratio of Mammary Uptake to Milk Protein Output. The quantity of $\mathrm{N}$ exported in milk output as TAA-N (data not shown; refer to Materials and Methods section for details of calculation) varied similarly to that of MPY $(P<0.01)$ in response to $\mathrm{NE}_{\mathrm{L}}$ or $\mathrm{MP}$ supplies, because the $\mathrm{CN}$ content in the milk true protein varied minimally with treatments (Table 5). The TAA-N ratio of mammary uptake to milk protein output (U:O ratio) was not different from 1 in all 4 diets $(P>0.26$; Table $9)$. The U:O ratio for group $1 \mathrm{AA}-\mathrm{N}$ was also not different from 1 for all diets $(P>0.20)$, but the $\mathrm{U}$ :O ratios for EAA-N, group $2 \mathrm{AA}-\mathrm{N}$, and BCAA-N were higher than $1(P \leq 0.03)$, whereas the ratio for NEAA-N was lower than $1(P \leq 0.01)$. 
Table 9. Effects of $\mathrm{NE}_{\mathrm{L}}$ and MP supplies on clearance rates of groups of AA and uptake:output ratio (U:O) of AA

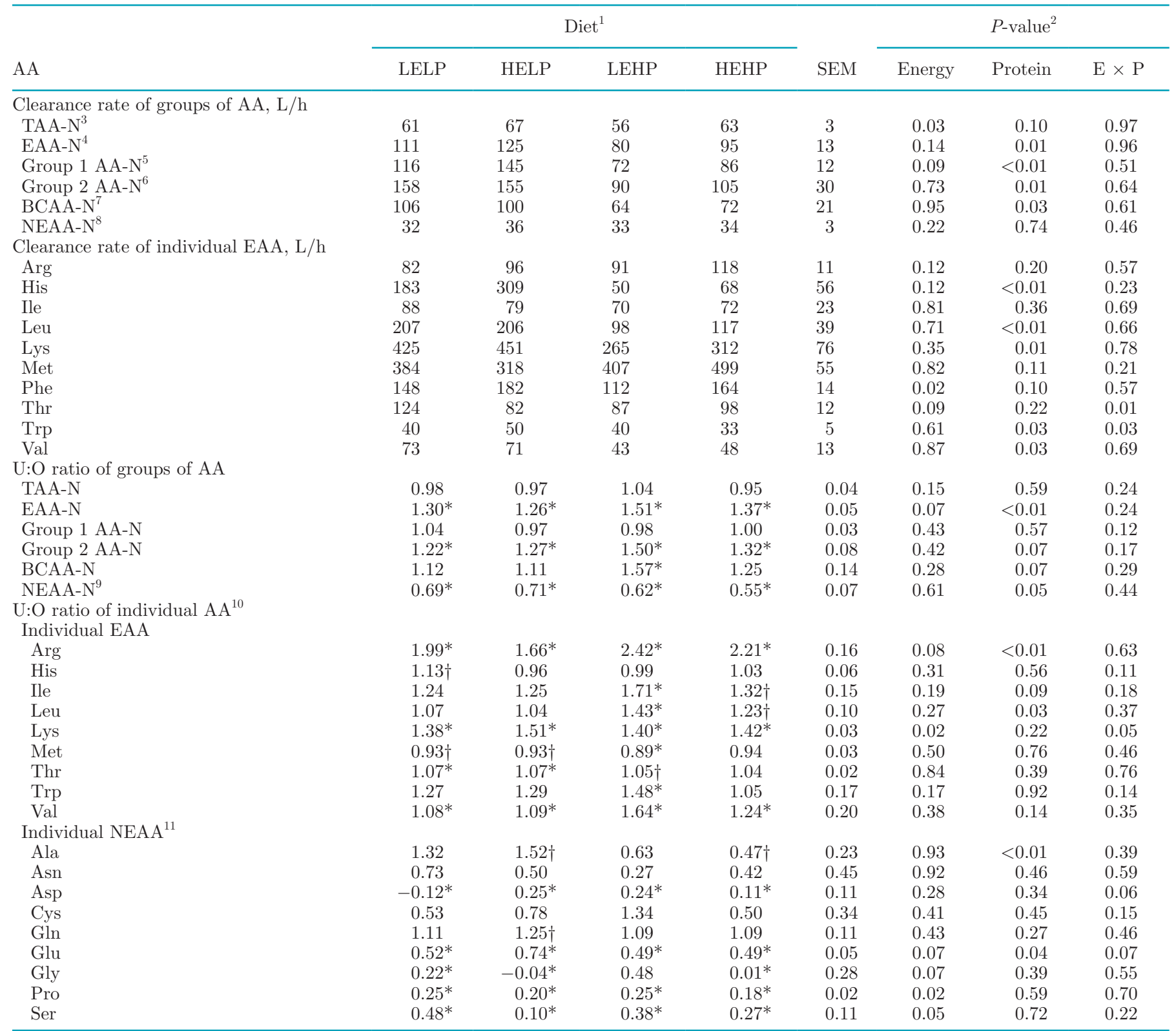

${ }^{1}$ LELP $=$ low energy and low protein; HELP $=$ high energy and low protein; LEHP = low energy and high protein; HEHP $=$ high energy and high protein.

${ }^{2} P$-values correspond to the effect of energy supply (LE vs. HE), effect of protein supply (LP vs. HP), and interaction between energy and protein $(\mathrm{E} \times \mathrm{P})$.

${ }^{3}$ TAA-N $=$ total AA on nitrogen basis.

${ }^{4}$ EAA-N = sum of $\mathrm{N}$ from Arg, His, Ile, Leu, Lys, Met, Phe, Thr, Trp, and Val.

${ }^{5}$ Group 1 AA-N = sum of $\mathrm{N}$ from His, Met, Phe, Trp, and Tyr.

${ }^{6}$ Group 2 AA-N $=$ sum of $\mathrm{N}$ from Ile, Leu, Lys, and Val.

${ }^{7}$ BCAA-N = branched-chain AA on nitrogen basis; sum of $\mathrm{N}$ from Ile, Leu, and Val.

${ }^{8}$ NEAA-N $=$ sum of N from Ala, Asn, Asp, Cit, Cys, Gln, Glu, Gly, Orn, Pro, Ser, Tau, and Tyr.

${ }^{9}$ For U:O ratio only, NEAA-N = sum of N from Ala, Asn, Asp, Cys, Gln, Glu, Gly, Pro, Ser, and Tyr.

${ }^{10} \mathrm{U}$ :O ratio of (Phe + Tyr) is assumed to equal 1 for calculation of mammary plasma flow using the Fick principle; no statistical analyses were made on these calculated parameters.

${ }^{11}$ Because Cit, Orn, and Tau have no output, their U:O ratio cannot be reported.

$* \mathrm{U}: \mathrm{O}$ ratio different from 1 at $P \leq 0.05$.

$\dagger$ Tendency at $P \leq 0.10$. 
We found no effect of $\mathrm{NE}_{\mathrm{L}}$ or $\mathrm{MP}$ supplies on the TAA-N U:O ratio. The EAA-N U:O ratio tended to decrease $(P=0.07)$ in response to HE compared with LE diets, but those of group 1 AA-N, group 2 AA-N, and NEAA-N were not affected by the $\mathrm{NE}_{\mathrm{L}}$ supply $(P$ $>0.41)$. For Lys, the U:O ratio was affected differently by the $\mathrm{NE}_{\mathrm{L}}$ supply $(\mathrm{E} \times \mathrm{P}$ interaction: $P=0.05)$ : it increased in LP diets $(P<0.01)$ but was not affected in HP diets $(P=0.59)$. We did not observe any $\mathrm{NE}_{\mathrm{L}}$ effect on the U:O ratio of the other EAA $(P>0.18)$ except a tendency for $\operatorname{Arg}(P=0.08)$ that decreased in HE compared with LE diets. With increased $\mathrm{NE}_{\mathrm{L}}$ supply, the U:O ratio of Pro and Ser decreased $(P<0.05)$, and that of Gly tended to decrease $(P=0.07)$, whereas that of Glu tended to increase $(\mathrm{E} \times \mathrm{P}$ interaction: $P=0.07)$ in response to HE compared with LE diets but only in LP diets $(P=0.02)$.

With HP compared with LP diets, the EAA-N U:O ratio increased $(P<0.01)$, that of group $2 \mathrm{AA}-\mathrm{N}$ and BCAA-N tended to increase $(P=0.07)$, and that of NEAA-N decreased $(P=0.05)$. Increasing the MP supply had no effect on U:O ratios of individual EAA except for Arg and Leu, which increased $(P \leq 0.03)$, and for Ile, which tended to increase $(P=0.09)$. Increasing the MP supply decreased $(P \leq 0.04)$ the $\mathrm{U}: \mathrm{O}$ ratio of Ala and Glu.

Nitrogen Efficiency and Estimated Metabolizable Protein and AA Efficiencies. Nitrogen efficiency, which is the proportion of $\mathrm{N}$ intake recovered in milk, varied between 0.34 in HELP and 0.22 in LEHP. It increased by $13 \%$ in HE compared with LE diets $(P$ $=0.04$; Table 10) and decreased by $24 \%$ in response to HP compared with LP diets $(P<0.01)$. The estimated MP_eff (Table 10) showed great variation in response to the 4 diets, averaging in ascending order 0.44 (LEHP), 0.55 (HEHP), 0.76 (LELP), and 0.95 (HELP). With increasing $\mathrm{NE}_{\mathrm{L}}$ supply, the estimated MP_eff increased by 0.15 but with an $\mathrm{E} \times \mathrm{P}$ interaction $(P<0.01)$ : the increment of estimated MP_eff in response to HE compared with LE diets was higher in the LP diets $(+0.19)$ compared with the HP diets $(+0.10)$. Because endogenous urinary losses and scurf protein estimations are based on BW, TAA-N in these export proteins were not affected by the diets $(2.1 \mathrm{~mol}$ $\mathrm{N} / \mathrm{d}$ and $0.1 \mathrm{~mol} \mathrm{~N} / \mathrm{d}$, respectively). Moreover, TAA-N supply expressed in mol $\mathrm{N} / \mathrm{d}$ had the same variations of AA supply as previously mentioned (Table 4). The same trends as MP_eff were observed for efficiency of TAA-N, because TAA-N differs from MP only by the exclusion of Cys and Trp $(P<0.01)$, and for all estimated individual EAA efficiencies $(P<0.01)$. An $\mathrm{E} \times$ $\mathrm{P}$ interaction $(P<0.01)$ was observed for TAA-N and for the individual EAA efficiencies, except that the $\mathrm{E} \times$ $\mathrm{P}$ interaction tended to be significant $(0.06 \leq P \leq 0.09)$ for the estimated efficiencies of Lys, Thr, and Val and was not significant $(P=0.74)$ for estimated Met_eff.

Contrary to the effect seen with increasing $\mathrm{NE}_{\mathrm{L}}$ supply, increasing MP supply decreased estimated MP_eff by 0.36 , and also decreased TAA-N and all estimated individual EAA efficiencies $P<0.01$ ), with the $\mathrm{E} \times \mathrm{P}$ interaction indicating that the decrease was greater in HE than in LE diets. No interaction $(P=0.79)$ was observed on the estimated catabolism of TAA-N.

For all individual EAA, we observed the highest estimated efficiencies with the HELP diet and the lowest with the LEHP diet, as also observed for MP. However, the magnitude of the differences varied between individual AA. The estimated efficiencies of Ile, Leu, Lys, Phe, Thr, and Val varied similarly to that of estimated MP_eff (from +19 to $+24 \%$ with HE vs. LE diets and from -34 to $-38 \%$ with HP vs. LP diets). In contrast, Arg and His had the highest variations of estimated efficiencies $(+38 \%$ and $+33 \%$ with $\mathrm{HE}$ vs. LE diets, and $-62 \%$ and $-46 \%$ with HP vs. LP diets for Arg and His, respectively). In contrast, Met showed the least variation $(+13 \%$ with $\mathrm{HE}$ vs. $\mathrm{LE}$ diets and $-27 \%$ with HP vs. LP diets). With the HELP diet, these 3 AA presented the highest estimated efficiencies compared with the other EAA; His_eff and Arg_eff were greater than $1(P \leq 0.05)$, whereas Met_eff $(0.95)$ tended to be less than 1. All the other estimated efficiencies of individual AA were less than 1 regardless of the diets $(P \leq 0.05)$.

\section{DISCUSSION}

\section{Milk Protein Yield Increased Through Different Mechanisms in Response to $N E_{L}$ or MP Supplies}

In the present trial, we created great variations in $\mathrm{NE}_{\mathrm{L}}$ $(+30 \%$, between LE and HE diets) and in MP supplies $(+78 \%$, between LP and HP diets). These variations allowed analysis of the effects on AA metabolism of the extreme values of $\mathrm{NE}_{\mathrm{L}}$ and $\mathrm{MP}$ supplies (from very low to high supplies) used to predict the MPY response in INRA (2018). However, we did not study the effects of gradual changes in $\mathrm{NE}_{\mathrm{L}}$ or MP supplies. Increasing $\mathrm{NE}_{\mathrm{L}}$ (between LE and HE diets) and MP supplies (between LP and HP diets) increased MPY similarly (19 and $15 \%$, respectively) but through different mechanisms at the MG level, demonstrating the high metabolic flexibility of the MG. The increased MG uptake of TAA-N in response to HE compared with LE diets was explained by increased mammary plasma flow, whereas the AV differences of TAA-N and EAA-N decreased. Increasing the $\mathrm{NE}_{\mathrm{L}}$ supply through increased DMI and different starch contents of the dietary concentrates, as performed in this trial, increased the mammary plasma 
Table 10. Effects of $\mathrm{NE}_{\mathrm{L}}$ and MP supplies on the partition of the TAA-N (total AA on nitrogen basis, mol of N/d) exported and on estimated efficiencies based on INRA (2018) and Lapierre et al. (2016)

\begin{tabular}{|c|c|c|c|c|c|c|c|c|}
\hline \multirow[b]{2}{*}{ Item } & \multicolumn{4}{|c|}{$\operatorname{Diet}^{1}$} & \multirow[b]{2}{*}{ SEM } & \multicolumn{3}{|c|}{$P$-value ${ }^{2}$} \\
\hline & LELP & HELP & LEHP & HEHP & & Energy & Protein & $\mathrm{E} \times \mathrm{P}$ \\
\hline Nitrogen efficiency ${ }^{3}$ & 0.312 & 0.333 & 0.224 & 0.253 & 0.008 & $<0.01$ & $<0.01$ & 0.40 \\
\hline $\begin{array}{l}\text { TAA-N } \\
\text { Estimated supply }\end{array}$ & 15.5 & 14.9 & 27.0 & 27.5 & 1.0 & 0.90 & $<0.01$ & 0.19 \\
\hline Measured milk & 7.3 & 8.4 & 8.2 & 9.9 & 0.5 & $<0.01$ & $<0.01$ & 0.15 \\
\hline Estimated efficiency & $0.720^{*}$ & $0.897^{*}$ & $0.417^{*}$ & $0.517^{*}$ & 0.008 & $<0.01$ & $<0.01$ & $<0.01$ \\
\hline \multicolumn{9}{|c|}{ Efficiencies of individual EAA } \\
\hline Arg & 0.94 & $1.32^{*}$ & $0.37^{*}$ & $0.48^{*}$ & 0.02 & $<0.01$ & $<0.01$ & $<0.01$ \\
\hline His & $0.80^{*}$ & $1.08^{*}$ & $0.44^{*}$ & $0.57^{*}$ & 0.01 & $<0.01$ & $<0.01$ & $<0.01$ \\
\hline Ile & $0.68^{*}$ & $0.81^{*}$ & $0.45^{*}$ & $0.54^{*}$ & 0.01 & $<0.01$ & $<0.01$ & 0.07 \\
\hline Leu & $0.67^{*}$ & $0.83^{*}$ & $0.43^{*}$ & $0.52 *$ & 0.01 & $<0.01$ & $<0.01$ & $<0.01$ \\
\hline Lys & $0.72^{*}$ & $0.85^{*}$ & $0.46^{*}$ & $0.55^{*}$ & 0.01 & $<0.01$ & $<0.01$ & 0.07 \\
\hline
\end{tabular}

${ }^{1}$ LELP $=$ low energy and low protein; HELP = high energy and low protein; LEHP = low energy and high protein; HEHP = high energy and high protein.

${ }^{2} P$-values correspond to the effect of energy supply (LE vs. HE), effect of protein supply (LP vs. HP), and interaction between energy and protein $(\mathrm{E} \times \mathrm{P})$.

${ }^{3}$ Ratio of $\mathrm{N}$ in milk to $\mathrm{N}$ intake.

${ }^{4} \mathrm{MP} \_$eff $=\mathrm{MP}$ efficiency.

${ }^{5}$ TAA-N = total AA on nitrogen basis; sum of N from Arg, His, Ile, Leu, Lys, Met, Phe, Thr, Val, Ala, Asx, Glx, Gly, Pro, Ser, and Tyr-i.e., total of 16 AA, excluding Cys and Trp.

${ }^{6} \mathrm{MFP}=$ metabolic fecal protein.

${ }^{7}$ Estimated catabolism $=$ supply - endogenous urinary losses - milk true protein yield - metabolic fecal protein - scurf.

*Different from 1 at $P \leq 0.05$.

$\dagger$ Tendency at $P \leq 0.10$.

flow, as previously observed when greater $\mathrm{NE}_{\mathrm{L}}$ supply was achieved through post-ruminal glucose or ruminal propionic acid infusion (Raggio et al., 2006a; Lemosquet et al., 2010a). We cannot exclude the possibility that the increased mammary plasma flow might also be explained by increased DMI, as feed restriction decreased it (Lough et al., 1990; Guinard-Flament et al., 2006, 2007). However, such a restriction decreased both $\mathrm{NE}_{\mathrm{L}}$ and MP supplies, contrary to the results of our trial. In contrast, in response to HP compared with LP diets, TAA-N uptake increased only through increased mammary AV differences in TAA-N, driven by EAA, with no change in mammary plasma flow.

The MG flexibility was also characterized by the MG uptake response to $\mathrm{HE}$ compared with LE diets, or HP compared with LP diets, which differed among AA. On the one hand, the uptake of group 1 AA-N increased in response to both $\mathrm{HE}$ compared with $\mathrm{LE}$ diets and HP compared with LP diets. In fact, the increment in MG uptake paralleled the increment in MPY for these AA, as indicated by the constant $\mathrm{U}: \mathrm{O}$ ratio of group 1 AA-N. The latter also did not differ from 1 , indicating a stoichiometric transfer of the MG uptake of these AA to milk protein, as initially proposed by Mepham (1982) and previously reported (Lemosquet et al., 2010a; Lapierre et al., 2012). This also suggested no variation in intramammary metabolism of these AA with dietary changes. In addition, the mammary clearance rate of group $1 \mathrm{AA}-\mathrm{N}$ increased in response to HE compared with LE diets, suggesting an increase in mammary transport capacity and intracellular utilization of these AA (Hanigan et al., 1998). On the other hand, increasing the $\mathrm{NE}_{\mathrm{L}}$ supply only tended to increase the uptake of group $2 \mathrm{AA}-\mathrm{N}$, mainly driven by Lys because there was no effect on BCAA-N; in fact, Lys uptake represented the major contributor (50\%) to the increased EAA-N uptake. In contrast, increasing MP supply increased uptake of group 2 AA-N and BCAA-N, and Arg, Leu, Ile, and Lys all contributed to the increased EAA-N uptake $(33,18,11$, and $11 \%$ respectively). Increasing the $\mathrm{NE}_{\mathrm{L}}$ supply also tended to increase NEAA-N uptake, whereas increasing the MP supply did not change it. Overall, MG uptake variations of the $\mathrm{AA}$ groups in response to $\mathrm{NE}_{\mathrm{L}}$ or $\mathrm{MP}$ 
supplies are consistent with the literature either from meta-analysis for increased $\mathrm{NE}_{\mathrm{L}}$ through increased propionic acid or intestinal glucose absorption (Lemosquet et al., 2010a) or MP supplies (Lapierre et al., 2012), or from individual experiments for $\mathrm{NE}_{\mathrm{L}}$ or $\mathrm{MP}$ supplies (e.g., Raggio et al., 2006a; Rius et al., 2010b). However, increasing $\mathrm{NE}_{\mathrm{L}}$ through rumen infusion of propionate or post-ruminal infusion of glucose did not increase uptake of AA from group 2 (Lemosquet et al., 2010a) but increased that of NEAA-N (Raggio et al., 2006a).

Finally, differences in intramammary metabolism also suggested high metabolic mammary flexibility. The U:O ratio of group 2 AA-N was always greater than 1 , which indicates intramammary metabolism of these AA for functions other than supporting MPY. There is indeed a need for mammary synthesis of NEAA, for which the $\mathrm{U}: \mathrm{O}$ ratio was always lower than 1 . As the TAA-N U:O ratio was not different from 1 and was not affected by dietary changes, the $\mathrm{N}$ of group 2 AA was probably transaminated to NEAA synthesized within the mammary gland (Lapierre et al., 2003, 2009). In addition, the Arg U:O ratio was always higher than 1.5 , as also previously reported (Doepel and Lapierre, 2010). This indicated that Arg could be used to support mammary NEAA de novo synthesis, namely Pro, whose U:O ratio was lower than 0.25 . The excess uptake relative to MPY of AA from group 2 did not increase in HE compared with LE diets. Furthermore, the nonresponse of Arg uptake led to a decreased $\mathrm{U}: \mathrm{O}$ ratio in $\mathrm{HE}$ compared with LE diets. In HELP, the increased Lys U:O ratio could be used to compensate for this decreased Arg $\mathrm{U}: \mathrm{O}$ ratio and supply $\mathrm{N}$ for the mammary synthesis of NEAA such as Ser, whose U:O ratio decreased in HE compared with LE diets. This result was consistent with Lapierre et al. (2009), who observed mammary transfer of the $\mathrm{N}$ from Lys to NEAA, including Ala, Glu, and Ser. In contrast, in response to HP compared with LP diets, the increased excess of group 2 AA-N and Arg relative to output ( $\mathrm{U}: \mathrm{O}$ ratio: $P=0.07$ ) was probably used to support de novo NEAA synthesis. In response to HP compared with LP diets, higher intramammary catabolism was suggested by the increased $\mathrm{U}: \mathrm{O}$ ratio of group 2 AA-N. In fact, we can consider that the first step in catabolism of the group $2 \mathrm{AA}$ occurred within the $\mathrm{MG}$, because their $\mathrm{N}$ are transaminated to NEAA (Mepham, 1982). This is probably what occurs with Leu, which is deaminated to methyl oxopentanoate before oxidation. The oxidation to $\mathrm{CO}_{2}$ of at least the first carbon of Leu increased with increased MP supply through post-ruminal CN infusion (Raggio et al., 2006a), which is proof of group 2 AA-N catabolism. Overall, MPY increased in response to $\mathrm{NE}_{\mathrm{L}}$ and $\mathrm{MP}$ supplies through different mechanisms, consistent with the fact that no $\mathrm{E} \times \mathrm{P}$ interaction was observed in the
MPY responses. Consequently, the effects of $\mathrm{NE}_{\mathrm{L}}$ and MP supplies were additive, as already reported (Clark et al., 1977; Broderick, 2003; Raggio et al., 2006a). In contrast, Brun-Lafleur et al. (2010) reported an E $\times$ $\mathrm{P}$ interaction, but their experiment was designed more specifically to detect such an interaction. These different mechanisms (variations of mammary plasma flow and AV differences, different increased uptakes of groups of AA, and changes in mammary metabolism) provided strong evidence of high metabolic mammary flexibility.

\section{Different Partitions Explained Variations of Efficiency of Utilization of MP}

Although independent increases in $\mathrm{NE}_{\mathrm{L}}$ and $\mathrm{MP}$ supplies increased MPY by a similar magnitude, their respective effects on MP_eff was different. Because the estimated MP_eff and TAA-N_eff differed only by the exclusion of Cys and Trp from TAA, the same conclusions can be applied to these 2 efficiencies. Increasing the $\mathrm{NE}_{\mathrm{L}}$ supply increased the estimated MP_eff, as previously reported by Hanigan et al. (1998) and Daniel et al. (2016) for CP and MP efficiencies, but to a higher extent in LP than in HP diets. Increasing the $\mathrm{NE}_{\mathrm{L}}$ supply did not affect the calculated MP supply but increased MPY. In contrast, the estimated MP_eff decreased in HP compared with LP diets; this effect of MP supply has been well documented (Doepel et al., 2004; Metcalf et al., 2008; INRA, 2018). This decrease, observed in the present experiment, is the result of the increase in MP supply $(+15 \%)$, as observed previously (Metcalf et al., 2008). These efficiencies were only estimated, with no direct measurement on MP or AA duodenal flow, consistent with previous studies (Metcalf et al., 2008; Daniel et al., 2016) that also estimated MP_eff or AA_eff and did not directly measure MP and AA duodenal flow. Nevertheless, the trends of efficiency variations were similar between the different feeding systems; we must keep in mind that the absolute variations of efficiency are valid only within the feeding system used to estimate both the supplies and the nonproductive functions. In the present experiment, we used the INRA (2018) feeding system because this new system revisited not only the supply but also the estimation of several protein exports. We cannot state that the absolute values of MP and AADI supplies or protein exported were completely accurate in the present experiment. However, rumen N degradation of each feed was determined (Table 1) to improve the accuracy of the prediction of MP supply. Nevertheless, the diet changes may not have achieved their full effect because of the short duration (2-wk period) for adaptation of the rumen microbial population. In addition, as 
mentioned in our Materials and Methods section, the contributions of protein mobilization in MP supply or protein accretion in export proteins were not taken into account in our calculations of efficiencies. Determining protein accretion or mobilization through monitoring BW is unrealistic because of the short duration of the experimental periods. If we had used the exact INRA (2018) calculations, it would have involved including fat and subsequent protein mobilizations in 3 of the diets because of the predicted negative energy balance (in Mcal/d, LELP: -3.8; LEHP: -4.9; HEHP: -1.2). This scenario cannot be totally excluded in LE diets with the 2 -wk duration of the experimental periods. In contrast, fat and protein accretion would have to be included in the HELP diet, linked to the predicted positive energy balance $(1.0 \mathrm{Mcal} / \mathrm{d})$ and the lowest plasma NEFA concentration (in $\mu M$, LELP: 170; HELP: 85; LEHP: 142; HEHP: $117 ; P_{\mathrm{E}}<0.01, P_{\mathrm{P}}=0.87$, and $\left.P_{\mathrm{E} \times \mathrm{P}}=0.01\right)$. However, in HELP, the efficiencies of MP, TAA-N and each EAA were higher than in the 3 other diets, and the efficiencies of 3 EAA (Arg, Met, His) were close to or even higher than 1, suggesting that protein mobilization might be the highest in this diet. Therefore, it would be unrealistic to assign a protein accretion value in this treatment, as proposed by INRA (2018). Interestingly, in the present experiment, the variations of MPY predicted $(+125 \mathrm{~g}$ in HE vs. LE, and $+99 \mathrm{~g}$ in HP vs. LP) using the INRA (2018) feeding system without taking account protein mobilization or accretion were close to the observed MPY $(+129 \mathrm{~g}$ in $\mathrm{HE}$ vs. LE; $+108 \mathrm{~g}$ in HP vs. LP). In fact, the estimation of MPY in INRA (2018) depends both on the calculated MP supply and on the estimation of other proteins exported; MP_eff is the ratio between both. Consequently, it was relevant to analyze the variations in MP and TAA-N efficiencies despite uncertainties as to supplies and protein exported, especially accretion.

Metabolic fecal protein and endogenous urinary loss, both considered export proteins, affect AA partitioning and all the estimated efficiencies. This supplementary information was needed to analyze the effect of $\mathrm{NE}_{\mathrm{L}}$ supply, because the increment of efficiencies in HE compared with LE diets was the result of increased MPY and metabolic fecal protein, due to increased DMI. An increment of metabolic fecal protein with greater DMI was already proposed by Schneider (1934) and therefore was estimated for the HE diets $(0.8 \mathrm{~mol} \mathrm{~N} / \mathrm{d})$, for which the DMI of the cows was $4.6 \mathrm{~kg} / \mathrm{d}$ greater than with the LE diets. Increasing $\mathrm{NE}_{\mathrm{L}}$ supply did not affect TAA-N supply, estimated scurf protein, or endogenous urinary loss (based on BW; Sauvant et al., 2015; Lapierre et al., 2016). The increased TAA-N_eff depended on the increased MPY and metabolic fecal protein, the latter representing about $64 \%$ of the mea- sured increase in TAA-N output in milk $(1.4 \mathrm{~mol} \mathrm{~N} / \mathrm{d})$. This also suggests a decreased catabolism of TAA-N in HE compared with LE diets, estimated by the difference between supply and export proteins $(-2.3 \mathrm{~mol}$ $\mathrm{N} / \mathrm{d}$ ), assuming no change in BW and no pregnancy. The lower arterial concentration of urea, as well as the lower NPN concentration in milk with the HE compared with LE diets could also suggest decreased catabolism when energy supply increased, as observed by Jonker et al. (1998), who reported a positive relation between urinary urea excretion and plasma urea concentration. The increased plasma urea concentration in HP compared with LP diets suggests higher catabolism of MP, resulting in increased urinary urea excretion. Overall, taking account of metabolic fecal protein export, even if it is only an estimation, clearly showed that MP and TAA-N efficiencies increased more than the increased MPY in HE compared with LE diets, through increased DMI. This changes our understanding of MP and TAAN efficiencies compared with the previous INRA (2007) calculation.

\section{Several Parameters Suggested Variations of Individual Efficiencies Among EAA}

Because individual EAA_eff varied differently with diets (Doepel et al., 2004), we opted to analyze wholebody metabolism of each EAA rather than the aggregation of AA as MP (Arriola Apelo et al., 2014). The differences between each EAA_eff result from differences in AA supply, whole-body utilization, or catabolism. Interestingly, some MG parameters could help to indicate which EAA were supplied in excess (e.g., increased $\mathrm{U}: \mathrm{O}$ ratio above 1) or which EAA were more limiting relative to others (e.g., highest MG clearance rate of some EAA), the latter probably corresponding to the least-catabolized AA (Arriola Apelo et al., 2014). In our trial, the MG clearance rates of Lys, Met, His, and Leu were higher than those of the other EAA in LP diets (Table 9), suggesting these 4 AA could be the most limiting AA. However, the Lys U:O was significantly ( $P$ $\leq 0.05$ ) higher than 1 , whereas Lys $\mathrm{U}: \mathrm{O}$ ratios close to 1 were reported in treatments deficient in Lys (Guinard et al., 1994; Lapierre et al., 2012; Haque et al., 2015). This suggests that Lys transport capacity was increased in LP compared with HP diets, to provide $\mathrm{N}$ for NEAA synthesis, and Lys was not the first limiting AA in the present experiment. Moreover, Leu U:O increased in HP compared with LP diets and became higher than 1 in the former diets, which suggested that this AA was not limiting in HP diets. In addition, the tendency $(P$ $=0.11$ ) for higher mammary clearance of Met in HP compared with LP diets (453 vs. $351 \mathrm{~L} / \mathrm{h}$, respectively) also suggests a greater deficiency of Met supply than of 
the other EAA supplies. This occurred when His, Leu, and Lys clearances were lower than the Met clearance rate as well as when these 3 clearance rates decreased (Table 9) in HP compared with LP diets. All of this could suggest that His and Met were the 2 first limiting AA in LP diets, whereas only Met was the first limiting AA in HP diets, as often observed when increasing MP supply (Broderick et al., 2008). In addition, this is also suggested by our estimated supplies of His and Met digestible in the intestine (Table 2) based on INRA (2018) AA feed tables, which were lower than the recommendations set at $2.4 \%$ of PDI $( \pm 0.2 \%$ of PDI) for both His and Met. In contrast, the estimated supplies of Leu and Lys digestible in the intestine were at or above the recommendations set at $8.5 \%$ and $7.0 \%$ of PDI ( $\pm 0.2 \%$ of PDI; INRA, 2018), suggesting that these AA are less limited than Met and His.

Interestingly, a similar conclusion regarding the most limiting AA was also reached through the analysis of individual EAA_eff. In fact, efficiencies of most individual EAA (Table 10) varied following a pattern similar to TAA_eff, but Arg and His had the largest variations of efficiencies, and Met had the smallest. As for MG clearance, the estimated efficiencies of His and Met were the highest of the EAA in LP, and the estimated Met_eff was the highest in HP, if Arg_eff is excluded. In HELP, the efficiencies of these $3 \mathrm{AA}$ were close to or higher than 1. As previously discussed, protein mobilization cannot be totally excluded with the 2 -wk duration of the experimental period. This might be the case for all EAA if protein mobilization occurs in HELP. However, in HELP, the highest predicted energy balance and the lowest plasma NEFA concentrations observed did not indicate fat and subsequent protein mobilization. Concerning Arg, a semi-essential AA, Doepel et al. (2004) suggested a de novo synthesis of $30 \mathrm{~g} / \mathrm{d}$, which, in the current study, represents half of the estimated digestible flow of Arg for the LP diets. Moreover, the high estimated Arg contribution to endogenous urinary losses due to creatine and creatinine urinary excretion (174 and $528 \mathrm{mmol} \mathrm{N} / \mathrm{d}$, respectively), was roughly equal to the amount of Arg exported in milk in HEHP (760 mmol N/d). Although these data add to our knowledge of Arg metabolism, more information is needed on true Arg supply, including de novo synthesis, to better characterize Arg_eff. Histidine efficiency was higher than Met_eff and higher than 1 in HELP; this high efficiency could be achieved without impeding protein mobilization. Indeed, an alternative endogenous source of His may contribute to His supply: His-dipeptides in muscular intracellular pools (carnosine and anserine) and hemoglobin could be used as an endogenous His supply (Lee et al., 2012; Lapierre et al., 2014; Giallongo et al., 2015) but not taken up by the MG for MPY (Haque et al., 2015). This could lead to efficiency higher than 1 when only the digestible flow is included into the estimated AA supply. Indeed, at low MP supply, Raggio et al. (2004) observed mammary uptake of His larger than the post-liver supply, and this was observed only for His. Additionally, His plasma concentration was lower in cows fed HELP than in those fed LELP $(\mathrm{E} \times \mathrm{P}$ interaction: $P=0.03$ ), which suggested a decreased His availability for other functions than MPY synthesis. If we hypothesize that the highest efficiencies define the most limiting AA, the limiting AA differed among diets and was probably His for HELP and Met for the 3 other diets. Overall, combining MG clearance rate and estimation of individual AA_eff improves our analysis of individual EAA utilization. Future research aimed at improving the models to predict protein exports (as metabolic fecal protein or endogenous urinary losses) and their associated AA composition would better define individual AA_eff or catabolism.

\section{CONCLUSIONS}

This experiment confirmed the high flexibility of the MG in contrasting nutritional situations. The increased MPY in response to wide variations of $\mathrm{NE}_{\mathrm{L}}$ and $\mathrm{MP}$, between low and high supplies, was associated with different changes in MG AA uptakes and metabolism. With increasing $\mathrm{NE}_{\mathrm{L}}$ supplies, EAA and NEAA uptakes increased or tended to increase, through an increase in mammary plasma flow, with no indications of substantial change in intramammary metabolism for most AA. However, with increasing MP supply, mammary uptake of EAA increased, whereas uptake of NEAA decreased. The excess uptake relative to milk protein outputs of Arg and group 2 AA increased in HP compared with LP diets; these AA could be used for de novo NEAA MG synthesis. Despite the fact that increasing $\mathrm{NE}_{\mathrm{L}}$ or $\mathrm{MP}$ supplies both increased MPY, these supplies respectively increased and decreased the estimated efficiencies. Increasing the $\mathrm{NE}_{\mathrm{L}}$ supply increased the estimated MP_eff and individual AA_eff, not only through an increase in the partition of $\mathrm{AA}$ toward MPY, with no change in AA supply, but also through the increase in metabolic fecal protein (linked to the increased DMI). With increased MP supply, the estimated MP_eff and AA_eff decreased, because AA exported in MPY increased to a lesser extent than the increased supply. Measurements of individual AA flows in metabolic fecal protein, individual AA digestibilities, or tissue protein mobilization (such as 3-methyl His) are required to confirm our conclusions about AA_eff. Nevertheless, analyses of MG metabolism parameters (as the U:O ratios of AA from group 2 and the clearance rate of some EAA), combined with the estima- 
tion of individual EAA_eff, could help determine the most limiting EAA, considering that the most limiting EAA has the highest efficiency. The most limiting AA was probably His in HELP and Met in the 3 other diets. The fact that some specific individual AA were involved in variations of MP_eff and in changes to MG metabolism suggests the possibility of developing a future feeding system that integrates individual AA_eff instead of only MP_eff. The great challenge will be, in future, to confirm these calculated variations of individual AA_eff using less-invasive methods.

\section{ACKNOWLEDGMENTS}

This experiment was supported by the Institut national de la recherche agronomique (INRA, Paris, France), and the C. Omphalius Convention Industrielle de Formation par la Recherche (CIFRE) PhD grant is supported by Adisseo S.A.S. (Antony, France). The authors acknowledge $\mathrm{H}$. Rulquin (INRA) for his help in preparing the experiment; F. Bardey (INRA) for initial data analyses; E. Pascal (Clinique Vétérinaire des Faluns, Saint Grégoire, France) and R. Delagarde (INRA) for animal surgeries; D. Chevrel, A. Cozien, and J. L. Harel (INRA, Installation Expérimentale de Production Laitière) for animal management; M. Leonard and J. Renaud (Agriculture and Agri-Food Canada, Sherbrooke, Quebec) for the AA analyses; and N. Huchet, M. Texier, S. Marion, and T. Le Mouel (INRA) for their help in laboratory analyses. The manuscript was copy edited by Lorraine Doepel at Underline Editing Services (www.underlineedit.com).

\section{REFERENCES}

Arriola Apelo, S. I., J. R. Knapp, and M. D. Hanigan. 2014. Invited review: Current representation and future trends of predicting amino acid utilization in the lactating dairy cow. J. Dairy Sci. 97:4000-4017. https://doi.org/10.3168/jds.2013-7392.

Aufrère, J., D. Graviou, C. Demarquilly, R. Vérité, B. MichaletDoreau, and P. Chapoutot. 1991. Predicting in situ degradability of feed proteins in the rumen by two laboratory methods (solubility and enzymatic degradation). Anim. Feed Sci. Technol. 33:97116. https://doi.org/10.1016/0377-8401(91)90049-X.

Baumont, R., D. Sauvant, G. Maxin, P. Chapoutot, and P. Nozière. 2018a. Methods for feed evaluation and databases. Pages 403-409 in INRA Feeding System for Ruminants. Wageningen Academic Publishers, Wageningen, the Netherlands.

Baumont, R., D. Sauvant, G. Maxin, P. Chapoutot, G. Tran, A. Boudon, S. Lemosquet, and P. Nozière. 2018b. Calculation of feed values in INRA system: Feed table and prediction equations. Pages 411-439 in INRA Feeding System for Ruminants. Wageningen Academic Publishers, Wageningen, the Netherlands.

Broderick, G. A. 2003. Effects of varying dietary protein and energy levels on the production of lactating dairy cows. J. Dairy Sci. 86:1370-1381. https://doi.org/10.3168/jds.S0022-0302(03)73721 $-7$.

Broderick, G. A., M. J. Stevenson, R. A. Patton, N. E. Lobos, and J. J. Olmos Colmenero. 2008. Effect of supplementing rumen-pro- tected methionine on production and nitrogen excretion in lactating dairy cows. J. Dairy Sci. 91:1092-1102. https://doi.org/10 .3168/jds.2007-0769.

Brun-Lafleur, L., L. Delaby, F. Husson, and P. Faverdin. 2010. Predicting energy $\times$ protein interaction on milk yield and milk composition in dairy cows. J. Dairy Sci. 93:4128-4143. https://doi .org/10.3168/jds.2009-2669.

Calder, A. G., K. E. Garden, S. E. Anderson, and G. E. Lobley. 1999. Quantitation of blood and plasma amino acids using isotope dilution electron impact gas chromatography/mass spectrometry with U-C-13 amino acids as internal standards. Rapid Commun. Mass Spectrom. 13:2080-2083. https://doi.org/10.1002/(SICI)1097 -0231(19991115)13:21<2080::AID-RCM755>3.0.CO;2-O.

Cant, J. P., E. J. DePeters, and R. L. Baldwin. 1993. Mammary amino acid utilization in dairy cows fed fat and its relationship to milk protein depression. J. Dairy Sci. 76:762-774. https://doi.org/10 .3168/jds.S0022-0302(93)77400-7.

Cantalapiedra-Hijar, G., I. Ortigues-Marty, and S. Lemosquet. 2015. Diets rich in starch improve the efficiency of amino acids use by the mammary gland in lactating Jersey cows. J. Dairy Sci. 98:6939-6953. https://doi.org/10.3168/jds.2015-9518.

Clark, J. H., H. R. Spires, R. G. Derrig, and M. R. Bennink. 1977. Milk production, nitrogen utilization and glucose synthesis in lactating cows infused postruminally with sodium caseinate and glucose. J. Nutr. 107:631-644. https://doi.org/10.1093/jn/107.4.631.

Daniel, J.-B., N. Friggens, P. Chapoutot, H. Van Laar, and D. Sauvant. 2016. Milk yield and milk composition responses to change in predicted net energy and metabolizable protein: A meta-analysis. Animal 10:1975-1985. https://doi.org/10.1017/S1751731116001245.

Doepel, L., and H. Lapierre. 2010. Changes in production and mammary metabolism of dairy cows in response to essential and nonessential amino acid infusions. J. Dairy Sci. 93:3264-3274. https:// doi.org/10.3168/jds.2009-3033.

Doepel, L., D. Pacheco, J. Kennelly, M. Hanigan, I. Lopez, and H. Lapierre. 2004. Milk protein synthesis as a function of amino acid supply. J. Dairy Sci. 87:1279-1297. https://doi.org/10.3168/jds .S0022-0302(04)73278-6.

Farrell, H. M., R. Jimenez-Flores, G. T. Bleck, E. M. Brown, J. E. Butler, L. K. Creamer, C. L. Hicks, C. M. Hollar, K. F. Ng-KwaiHang, and H. E. Swaisgood. 2004. Nomenclature of the proteins of cows' milk - Sixth revision. J. Dairy Sci. 87:1641-1674. https://doi .org/10.3168/jds.S0022-0302(04)73319-6.

Giallongo, F., A. Hristov, J. Oh, T. Frederick, H. Weeks, J. Werner, H. Lapierre, R. Patton, A. Gehman, and C. Parys. 2015. Effects of slow-release urea and rumen-protected methionine and histidine on performance of dairy cows. J. Dairy Sci. 98:3292-3308. https:/ /doi.org/10.3168/jds.2014-8791.

Guinard, J., H. Rulquin, and R. Vérité. 1994. Effect of graded-levels of duodenal infusions of casein on mammary uptake in lacting cows. 1: Major nutrients. J. Dairy Sci. 77:2221-2231. https://doi.org/10 .3168/jds.S0022-0302(94)77165-4.

Guinard-Flament, J., E. Delamaire, P. Lamberton, and J. Peyraud. 2007. Adaptations of mammary uptake and nutrient use to oncedaily milking and feed restriction in dairy cows. J. Dairy Sci. 90:5062-5072. https://doi.org/10.3168/jds.2007-0259.

Guinard-Flament, J., E. Delamaire, S. Lemosquet, M. Boutinaud, and Y. David. 2006. Changes in mammary uptake and metabolic fate of glucose with once-daily milking and feed restriction in dairy cows. Reprod. Nutr. Dev. 46:589-598. https://doi.org/10.1051/ rnd:2006030.

Hanigan, M. D., J. P. Cant, D. C. Weakley, and J. L. Beckett. 1998. An evaluation of postabsorptive protein and amino acid metabolism in the lactating dairy cow. J. Dairy Sci. 81:3385-3401. https: //doi.org/10.3168/jds.S0022-0302(98)75903-X.

Haque, M. N., J. Guinard-Flament, P. Lamberton, C. Mustiere, and S. Lemosquet. 2015. Changes in mammary metabolism in response to the provision of an ideal amino acid profile at 2 levels of metabolizable protein supply in dairy cows: Consequences on efficiency. J. Dairy Sci. 98:3951-3968. https://doi.org/10.3168/jds.2014-8656.

Hurtaud, C., H. Rulquin, and R. Vérité. 1993. Effect of infused volatile fatty acids and caseinate on milk composition and coagulation in 
dairy cows. J. Dairy Sci. 76:3011-3020. https://doi.org/10.3168/ jds.S0022-0302(93)77640-7.

INRA (Institut national de la recherche agronomique). 1989. Ruminant Nutrition: Recommended Allowances and Feed Tables. R. Jarrige, ed. INRA, Paris, France.

INRA (Institut national de la recherche agronomique). 2007. Alimentation des bovins, ovins et caprins: Besoins des animaux - Valeurs des aliments-Tables INRA. Editions Quae, Versailles, France.

INRA (Institut national de la recherche agronomique). 2018. INRA Feeding System for Ruminants. Wageningen Academic Publishers, Wageningen, the Netherlands.

ISO. (International Organization for Standardization). 1999. ISO 9622: Whole milk. Determination of milk fat, protein and lactose content. Guidance on the operation of mid-infrared instruments. ISO, Geneva, Switzerland.

Jonker, J. S., R. A. Kohn, and R. A. Erdman. 1998. Using milk urea nitrogen to predict nitrogen excretion and utilization efficiency in lactating dairy cows. J. Dairy Sci. 81:2681-2692.

Lapierre, H., L. Doepel, E. Milne, and G. Lobley. 2009. Responses in mammary and splanchnic metabolism to altered lysine supply in dairy cows. Animal 3:360-371. https://doi.org/10.1017/ S1751731108003571.

Lapierre, H., G. E. Lobley, L. Doepel, G. Raggio, H. Rulquin, and S. Lemosquet. 2012. Triennial lactation symposium: Mammary metabolism of amino acids in dairy cows. J. Anim. Sci. 90:1708-1721. https://doi.org/10.2527/jas.2011-4645.

Lapierre, H., E. Milne, J. Renaud, and G. Lobley. 2003. Lysine utilisation by the mammary gland. Pages $777-780$ in Progress in Research on Energy and Protein Metabolism. EAAP publication no. 109. W. B. Souffrant and C. C. Metges, ed. Wageningen Academic Publishers, Wageningen, the Netherlands.

Lapierre, H., D. Ouellet, and G. Lobley. 2014. Estimation of histidine requirement in lactating dairy cows. J. Dairy Sci. 97(E-Suppl. 1):757. (Abstr.)

Lapierre, H., D. Ouellet, R. Martineau, and J. Spek. 2016. Key roles of amino acids in cow performance and metabolism: Considerations for defining amino acid requirements. Pages 205-218 in Proc. Cornell Nutrition Conference for Feed Manufacturers, East Syracuse, NY. Cornell University, Ithaca, NY.

Lee, C., F. Giallongo, A. Hristov, H. Lapierre, T. Cassidy, K. Heyler, G. Varga, and C. Parys. 2015. Effect of dietary protein level and rumen-protected amino acid supplementation on amino acid utilization for milk protein in lactating dairy cows. J. Dairy Sci. 98:1885-1902. https://doi.org/10.3168/jds.2014-8496.

Lee, C., A. Hristov, T. Cassidy, K. Heyler, H. Lapierre, G. Varga, M. De Veth, R. Patton, and C. Parys. 2012. Rumen-protected lysine, methionine, and histidine increase milk protein yield in dairy cows fed a metabolizable protein-deficient diet. J. Dairy Sci. 95:60426056. https://doi.org/10.3168/jds.2012-5581.

Lemosquet, S., J. Guinard-Flament, G. Raggio, C. Hurtaud, J. Van Milgen, and H. Lapierre. 2010a. How does increasing protein supply or glucogenic nutrients modify mammary metabolism in lactating dairy cows? Pages 175-186 in Energy and Protein Metabolism and Nutrition. EAAP publication no. 127. C. M. Crovetto, ed. Wageningen Academic Publishers, Wageningen, the Netherlands.

Lemosquet, S., G. Lobley, R. Koopman, L. J. C. van Loon, A. K. Kies, and H. Lapierre. 2010b. A large supply of phenylalanine is not oxidised by the mammary gland of dairy cows Pages 139-140 in Energy and Protein Metabolism and Nutrition. EAAP publication no. 127. C. M. Crovetto, ed. Wageningen Academic Publishers, Wageningen, the Netherlands.

Lough, D. S., D. L. Beede, and C. J. Wilcox. 1990. Effects of feed intake and thermal stress on mammary blood flow and other physiological measurements in lactating dairy cows. J. Dairy Sci. 73:325-332. https://doi.org/10.3168/jds.S0022-0302(90)78677-8.

Mepham, T. B. 1982. Amino acid utilization by lactating mammary gland. J. Dairy Sci. 65:287-298. https://doi.org/10.3168/jds.S0022 -0302(82)82191-7.

Metcalf, J. A., R. J. Mansbridge, J. S. Blake, J. D. Oldham, and J. R. Newbold. 2008. The efficiency of conversion of metabolisable protein into milk true protein over a range of metabolisable protein intakes. Animal 2:1193-1202. https://doi.org/10.1017/ S1751731108002140.

Michalet-Doreau, B., R. Vérité, and P. Chapoutot. 1987. Méthodologie de mesure de la dégradabilité in sacco de l'azote des aliments dans le rumen. Bull. Tech. CRZV Theix 69:5-7.

NRC (National Research Council). 2001. Nutrient Requirements of Dairy Cattle. 7th rev. ed. Natl. Acad. Press, Washington, DC.

Nichols, K., J. J. M. Kim, M. Carson, J. A. Metcalf, J. P. Cant, and J. Doelman. 2016. Glucose supplementation stimulates peripheral branched-chain amino acid catabolism in lactating dairy cows during essential amino acid infusions. J. Dairy Sci. 99:1145-1160. https://doi.org/10.3168/jds.2015-9912.

Raggio, G., S. Lemosquet, G. Lobley, H. Rulquin, and H. Lapierre 2006a. Effect of casein and propionate supply on mammary protein metabolism in lactating dairy cows. J. Dairy Sci. 89:43404351. https://doi.org/10.3168/jds.S0022-0302(06)72481-X.

Raggio, G., G. Lobley, S. Lemosquet, H. Rulquin, and H. Lapierre. 2006b. Effect of casein and propionate supply on whole body protein metabolism in lactating dairy cows. Can. J. Anim. Sci. 86:8189. https://doi.org/10.4141/A05-055.

Raggio, G., D. Pacheco, R. Berthiaume, G. Lobley, D. Pellerin, G. Allard, P. Dubreuil, and H. Lapierre. 2004. Effect of level of metabolizable protein on splanchnic flux of amino acids in lactating dairy cows. J. Dairy Sci. 87:3461-3472. https://doi.org/10.3168/ jds.S0022-0302(04)73481-5.

Rius, A. G, J. A. Appuhamy, J. Cyriac, D. Kirovski, O. Becvar, J. Escobar, M. L. McGilliard, B. J. Bequette, R. M. Akers, and M. D. Hanigan. 2010a. Regulation of protein synthesis in mammary glands of lactating dairy cows by starch and amino acids. J. Dairy Sci. 93:3114-3127. https://doi.org/10.3168/jds.2009-2743.

Rius, A. G., M. L. McGilliard, C. A. Umberger, and M. D. Hanigan. 2010b. Interactions of energy and predicted metabolizable protein in determining nitrogen efficiency in the lactating dairy cow. J. Dairy Sci. 93:2034-2043. https://doi.org/10.3168/jds.2008-1777.

Sauvant, D., G. Cantalapiedra-Hijar, L. Delaby, J.-B. Daniel, P. Faverdin, and P. Nozière. 2015. Actualisation des besoins protéiques des ruminants et détermination des réponses des femelles laitières aux apports de protéines digestibles dans l'intestin. Prod. Anim. 28:347-368.

Schneider, B. H. 1934. The relationship of the metabolic nitrogen of the faeces to body weight and to food intake for rats. Biochem. J. $28: 360-364$. 